Old Dominion University

ODU Digital Commons

\title{
Impacts of Multiple Environmental Changes on Long-Term Nitrogen Loading From the Chesapeake Bay Watershed
}

\author{
Shufen Pan \\ Zihao Bian \\ Hanqin Tian \\ Yuanzhi Yao \\ Raymond G. Najjar
}

See next page for additional authors

Follow this and additional works at: https://digitalcommons.odu.edu/ccpo_pubs

Part of the Climate Commons, and the Oceanography Commons

\section{Original Publication Citation}

Pan, S., Bian, Z., Tian, H., Yao, Y., Najjar, R. G., Friedrichs, M. A. M., . . Zhang, B. (2021). Impacts of multiple environmental changes on long-term nitrogen loading from the Chesapeake Bay watershed. Journal of Geophysical Research: Biogeosciences, 126(5), Article e2020JG005826, 1-18. https://doi.org/10.1029/ 2020JG005826. 


\section{Authors}

Shufen Pan, Zihao Bian, Hanqin Tian, Yuanzhi Yao, Raymond G. Najjar, Marjorie A.M. Friedrichs, Eileen E. Hofmann, Rongting $\mathrm{Xu}$, and Bowen Zhang 


\section{JGR Biogeosciences}

\author{
RESEARCH ARTICLE \\ 10.1029/2020JG005826 \\ Key Points: \\ - Nitrogen loading from Chesapeake \\ Bay watershed continually increased \\ from the 1900s to the 1990s and has \\ declined since then \\ - Key contributors to total $\mathrm{N}$ export \\ have changed over the past century \\ from atmospheric $\mathrm{N}$ deposition to \\ synthetic nitrogen fertilizer \\ - More effective management of \\ terrestrial non-point sources is \\ required to achieve water quality \\ goals
}

Supporting Information:

Supporting Information may be found in the online version of this article.

Correspondence to:

S. Pan,

panshuf@auburn.edu

Citation:

Pan, S., Bian, Z., Tian, H., Yao, Y., Najjar, R. G., Friedrichs, M. A. M., et al. (2021). Impacts of multiple environmental changes on longterm nitrogen loading from the Chesapeake Bay watershed. Journal of Geophysical Research: Biogeosciences, 126, e2020JG005826. https://doi. org/10.1029/2020JG005826

Received 3 MAY 2020

Accepted 18 MAR 2021 (c) 2021. American Geophysical Union. All Rights Reserved.

\section{Impacts of Multiple Environmental Changes on Long- Term Nitrogen Loading From the Chesapeake Bay Watershed}

\author{
Shufen $\operatorname{Pan}^{1}$ (D), Zihao Bian ${ }^{1}$ (D), Hanqin $\operatorname{Tian}^{1}$ (D), Yuanzhi Yao ${ }^{1}$ (D), \\ Raymond G. Najjar ${ }^{2}$ (D), Marjorie A. M. Friedrichs ${ }^{3}$ (D), Eileen E. Hofmann ${ }^{4}$ (D), \\ Rongting $\mathrm{Xu}^{1}{ }^{\mathbb{D}}$, and Bowen $\mathrm{Zhang}^{5}$ iD \\ ${ }^{1}$ International Center for Climate and Global Change Research, School of Forestry and Wildlife Sciences, Auburn \\ University, Auburn, AL, USA, ${ }^{2}$ Department of Meteorology and Atmospheric Science, The Pennsylvania State \\ University, University Park, PA, USA, ${ }^{3}$ Virginia Institute of Marine Science, William\& Mary, Gloucester Point, VA, USA, \\ ${ }^{4}$ Department of Ocean, Earth and Atmospheric Sciences, Center for Coastal Physical Oceanography, Old Dominion \\ University, Norfolk, VA, USA, ${ }^{5}$ Department of Environment, Geology, and Natural Resources, Ball State University, \\ Muncie, IN, USA
}

Abstract Excessive nutrient inputs from land, particularly nitrogen (N), have been found to increase the occurrence of hypoxia and harmful algal blooms in coastal ecosystems. To identify the main contributors of increased $\mathrm{N}$ loading and evaluate the efficacy of water pollution control policies, it is essential to quantify and attribute the long-term changes in riverine $\mathrm{N}$ export. Here, we use a state-of-theart terrestrial-aquatic interface model to examine how multiple environmental factors may have affected $\mathrm{N}$ export from the Chesapeake Bay watershed since 1900. These factors include changes in climate, carbon dioxide, land use, and $\mathrm{N}$ inputs (i.e., atmospheric $\mathrm{N}$ deposition, animal manure, synthetic $\mathrm{N}$ fertilizer use, and wastewater discharge). Our results estimated that ammonium $\left(\mathrm{NH}_{4}{ }^{+}\right)$and nitrate $\left(\mathrm{NO}_{3}{ }^{-}\right)$export increased substantially ( $66 \%$ for $\mathrm{NH}_{4}{ }^{+}$and $123 \%$ for $\mathrm{NO}_{3}{ }^{-}$) from the 1900 s to the 1990 s and then declined ( $32 \%$ for $\mathrm{NH}_{4}{ }^{+}$and $14 \%$ for $\mathrm{NO}_{3}{ }^{-}$) since 2000 . The temporal trend of dissolved organic nitrogen (DON) export paralleled that of dissolved inorganic $\mathrm{N}$, while particulate organic nitrogen export was relatively constant during 1900-2015. Precipitation was the primary driver of interannual variability in $\mathrm{N}$ export to the Bay. Wastewater discharge explained most of the long-term change in riverine $\mathrm{NH}_{4}{ }^{+}$and DON fluxes from 1900 to 2015. The changes in atmospheric deposition, wastewater, and synthetic fertilizer were responsible for the trend of riverine $\mathrm{NO}_{3}{ }^{-}$. In light of our model-based attribution analysis, terrestrial nonpoint source nutrient management will play an important role in achieving water quality goals.

Plain Language Summary Excessive nitrogen can enter estuarine and coastal areas from land, disturbing coastal ecosystems and causing serious environmental problems. The Chesapeake Bay is one of the regions that have experienced hypoxia and harmful algal blooms in recent decades. This study estimated nitrogen export from the Chesapeake Bay watershed (CBW) to the estuary from 1900 to 2015 by applying a state-of-the-art numerical model. Nitrogen loading from the CBW continually increased from the 1900s to the 1990s and has declined since then. The key contributors to nitrogen export have shifted from atmospheric nitrogen deposition (before the 1960s) to synthetic nitrogen fertilizer (after the 1980s). Antipollution policies and implementation measures have played critical roles in the decrease of nitrogen export since the 1980s, and further reduction in riverine nitrogen export will likely require regulation on the application of nitrogen fertilizer.

\section{Introduction}

The demand for producing more food and the combustion of fuel has substantially altered the global nitrogen $(\mathrm{N})$ cycle, causing an increase in reactive $\mathrm{N}$ in the atmosphere, on land, and in water (Galloway et al., 2004). Nitrogen plays an active role in estuarine ecosystems by influencing the rate of net primary production and subsequent biogeochemical processes (Feng et al., 2015; Schlesinger \& Bernhardt, 2013; Testa, $\mathrm{Li}$, et al., 2014). Large increases of $\mathrm{N}$ export from land into aquatic ecosystems have disrupted ecological balance and intensified eutrophication (Boesch et al., 2001; Burgin \& Hamilton, 2007; Kemp et al., 2005). Lateral $\mathrm{N}$ flux through riverine systems is a critical source of $\mathrm{N}$ from land into the coastal zone (Da et al., 2018; 
Friedrichs et al., 2019). A better understanding of the long-term riverine $\mathrm{N}$ dynamics under external forces is essential to disentangle the drivers of $\mathrm{N}$ pollution in the coastal zone and develop nutrient management strategies (Boyer, Howarth, et al., 2006; Irby \& Friedrichs, 2019).

The evolution of riverine $\mathrm{N}$ export is largely influenced by climate. Changes in climate (e.g., temperature and precipitation) can alter plant physiology, soil property, leaching, and runoff, further impacting $\mathrm{N}$ cycling in the terrestrial-aquatic system (Gleick, 1989; Tian, Xu, et al., 2020; Wagena et al., 2018). Specifically, soil temperature and soil moisture can affect chemical reaction rates and microbial activity, which control $\mathrm{N}$ dynamics in soils (e.g., mineralization/immobilization and nitrification/denitrification). In addition, precipitation and evapotranspiration largely determine the leaching rates of $\mathrm{N}$ through the soil profile. Interannual variability and extreme occurrences of $\mathrm{N}$ loading are dominated by precipitation across three-quarters of the continental United States (US) (Sinha \& Michalak, 2016; Sinha et al., 2017).

Regional anthropogenic activities, primarily land-use change, wastewater discharge, and agriculture, have substantially increased the amount of reactive $\mathrm{N}$ in the terrestrial-aquatic system (Boyer, Goodale, et al., 2002; Dupas et al., 2018). Land conversions among urban area, cropland, and other land-use types have dramatically changed the amount and distribution of point and non-point sources and have altered the $\mathrm{N}$ dynamics from land to rivers (Chen et al., 2017). For example, the exacerbated $\mathrm{N}$ pollution in Chinese watersheds from point sources is highly associated with untreated wastewater discharge from urban areas to rivers (W. Zhang et al., 2017). Non-point source N pollution due to agricultural activity and atmospheric deposition also plays an important role in degrading water quality in US coastal oceans (Shields et al., 2008; Tian, Xu, et al., 2020; Yang, Tian, Friedrichs, et al., 2015). Increased application of synthetic N fertilizer and livestock excretion have introduced a substantial amount of $\mathrm{N}$ into agricultural soils, inducing $\mathrm{N}$ losses through gas emissions, leaching, and runoff (Lu \& Tian, 2017; Schlesinger et al., 2006; Tian et al., 2019; R. Xu et al., 2019; Yang, Tian, Li, et al., 2016).

The Chesapeake Bay on the mid-Atlantic coast of the continental US is an example of a region exhibiting symptoms of N over-enrichment (Harding, Gallegos, et al., 2016; Harding, Mallonee, et al., 2016). The Chesapeake Bay watershed (CBW) has experienced a remarkable increase in population and urban area over the last century. Increased occurrence of bottom-water hypoxia, harmful algal blooms, and reduction in water clarity have been observed in the bay since the mid-twentieth century, coincident with these increased N fluxes (Bever et al., 2013; Hagy et al., 2004; Harding, Mallonee, et al., 2019; Kemp et al., 2005; Tango et al., 2005). The Chesapeake Bay Program (CBP) was initiated in 1983 and numerous targets have been set to reduce nutrient pollution. Modest improvement of bay water quality has been documented and ascribed to the practices of ecosystem restoration and water resource protection (Lefcheck et al., 2018; Testa, Kemp, \& Boynton et al., 2018; Q. Zhang, Murphy, et al., 2018). Investigating the long-term changes in riverine N export from the CBW can provide essential information to identify the main contributors of $\mathrm{N}$ loading and evaluate the efficacy of water pollution control policies.

Previous studies have evaluated the response of riverine N export to climate variability (Wagena et al., 2018), land conversions (Brush, 2009; Roberts \& Prince, 2010), and anthropogenic N inputs (Boyer, Goodale, et al., 2002) through inventory-based analysis (Hagy et al., 2004; Tango \& Batiuk, 2016), statistical approaches (Shields et al., 2008), empirical models (Howarth, Swaney,Billen, et al., 2012), and physically based watershed model (Shenk \& Linker, 2013). However, few studies have utilized a process-based biogeochemical model to simulate the land-aquatic $\mathrm{N}$ cycling driven by multiple environmental forces. Process-based models simultaneously considering the impact of climate and anthropogenic activities on $\mathrm{N}$ dynamics among the land-aquatic and atmospheric interface may help to better elucidate the mechanisms that control riverine $\mathrm{N}$ export in the study region (Yang, Tian, Friedrichs, et al., 2015).

In this study, we use a model representation of nitrogen and hydrological processes at the terrestrial-aquatic interface that incorporates a newly developed scale-adaptive water transport scheme in the Dynamic Land Ecosystem Model version 2.0 (DLEM 2.0) and applied it to quantify exports of ammonium $\left(\mathrm{NH}_{4}^{+}\right)$, nitrate $\left(\mathrm{NO}_{3}{ }^{-}\right)$, dissolved organic nitrogen (DON), and particulate organic nitrogen (PON) from the CBW into the estuary since 1900 . The model simulation was driven by time-series of gridded data from multiple environmental forcings (i.e., climate, atmospheric carbon dioxide concentrations $\left(\mathrm{CO}_{2}\right)$, and land-use change) and $\mathrm{N}$ inputs (i.e., atmospheric $\mathrm{N}$ deposition, wastewater, and animal manure and synthetic $\mathrm{N}$ fertilizer 


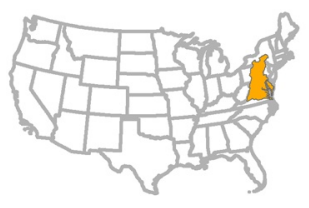

a

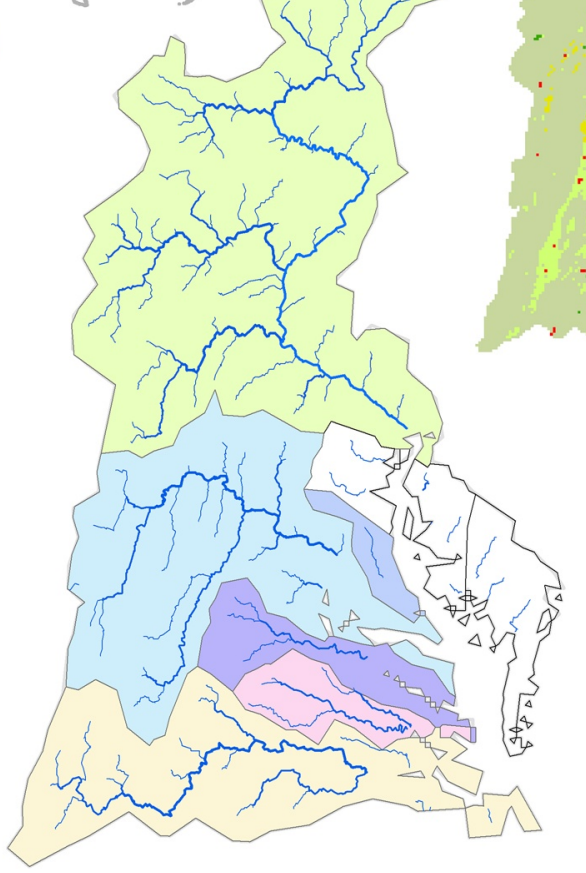

b
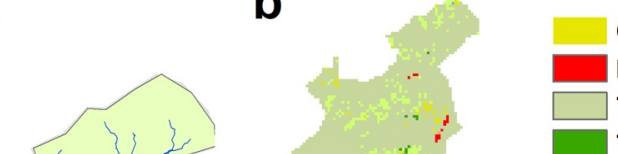

Cropland

Impervious Surface

Temperate Broadleaf Deciduous Forest

Temperate Broadleaf Evergreen Forest

Temperate Needleleaf Evergreen Forest Temperate Needleleaf Deciduous Forest Shrub

C3 Grass

Herbaceous Wetland

Woody Wetland
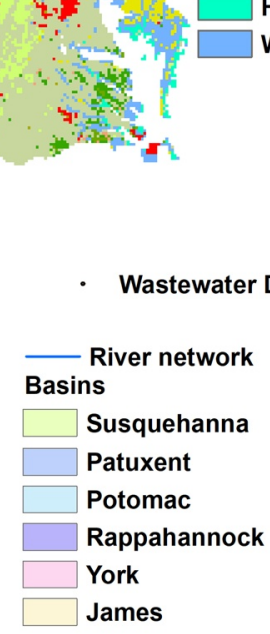

C

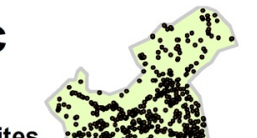

ischarge Sites

Figure 1. The Chesapeake Bay watershed. (a) Sub-basins of the watershed; (b) the major land cover types; and (c) the distribution of wastewater discharge sites industrial wastewater discharge, municipal wastewater discharge, and combined sewer overflows.

use). The contributions of these factors to changes in $\mathrm{N}$ export were analyzed through factorial simulation experiments.

\section{Methods}

\subsection{Study Area}

The Chesapeake Bay, with 18,803 km of tidal shoreline, is the largest estuary in North America. The surrounding watershed encompasses $166,000 \mathrm{~km}^{2}$, including portions of six states (New York, Pennsylvania, West Virginia, Maryland, Delaware, and Virginia) and the District of Columbia. More than 100,000 rivers and streams thread through the watershed and the six largest rivers that drain into the Chesapeake Bay are the Susquehanna, Potomac, Rappahannock, York, James, and Patuxent Rivers (Figure 1a). Over 18 million people live in the watershed and more than 8,500 wastewater discharge sites are distributed across the watershed (Figure 1c). Within the watershed, the major land-use types in 2015 were forest, cropland, and urban impervious surface (Figure 1b).

\subsection{Model Description}

DLEM 2.0 is an integrated process-based model that couples terrestrial biophysics, plant phenology, soil biogeochemistry, and vegetation dynamics, and disturbance to simulate the responses of water, carbon, $\mathrm{N}$, and phosphorus cycling to anthropogenic activities and climate variability (Figure 2). The overview of the land component of DLEM has been reported in previous publications (M. Liu et al., 2013; Pan, Tian, et al., 2015; Pan, Yang, et al., 2020; Tian, Chen, et al., 2010; Tian, Lu, et al., 2016). DLEM is capable of simulating key N-related processes, including mineralization, nitrification, denitrification, immobilization, volatilization, $\mathrm{N}$ uptake, $\mathrm{N}$ fixation, and $\mathrm{N}$ leaching (Tian, Lu, Melillo, et al., 2012; Tian, Yang, Xu, et al., 2019; 


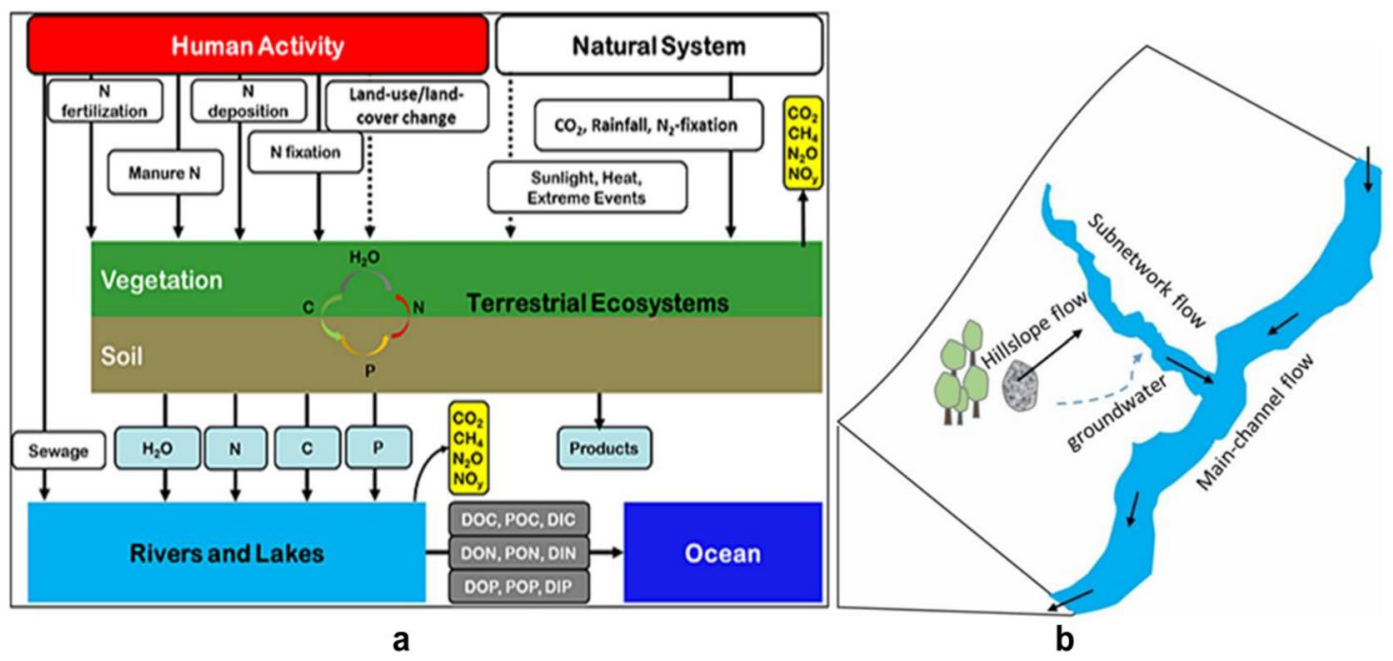

Figure 2. (a) The general framework of DLEM and the terrestrial-aquatic interface, which is coupled with (b) conceptual model of the scale-adaptive water transport scheme.

R. T. Xu et al., 2018). In DLEM 2.0, we coupled biogeochemical and hydrological cycles to simulate daily, spatially explicit patterns of runoff, and nutrient and carbon leaching from land to the ocean systems (Ren et al., 2016; Tian, Xu, et al., 2020; Tian, Yang, Najjar, et al., 2015; Yang, Tian, Friedrichs, et al., 2015). The water and nutrient transport module in the previous version of DLEM only considered the transport process between grid cells. Here, we improved the water and nutrient transport processes within grid cells and coupled them with biogeochemical processes in DLEM 2.0- the improved terrestrial-aquatic interface. Then, we applied this improved model to quantify the riverine $\mathrm{N}$ exports.

\subsection{Water and Nutrient Processes Within Each Grid Cell}

In this study we improved the river module and the associated biogeochemical processes of DLEM. A scale-adaptive water transport scheme (Model of Scale Adaptive River Transport, MOSART) (H. Li et al., 2013) was coupled into DLEM to quantify the daily river discharge of each grid cell in the landform (Figure 2b). The newly developed module separates the water transport within the grid cells into three subgrid processes: hillslope flow, subnetwork flow, and main channel flow. The hillslope flow merges water from surface runoff and flows into subnetworks. The subnetwork flow receives water from hillslope flow and subsurface runoff, and drains into the main river channel of the unit. The main river channel receives water from local subnetworks and upstream grid cells, and ultimately flows into the downstream grid cell. The river-routing processes are fully physically based and simulated with the kinematic wave method (Te Chow, 2010), which requires physical variables (channel length, bankfull depth, channel slope, and channel roughness) derived from fine-resolution hydrography data (H.-Y. Li et al., 2015). Vertical soil moisture movement from the earth surface to the root zone was lumped together, and the lateral groundwater transport from a groundwater pool to the local subnetworks was simulated with parameterized outflow rates. Additional biogeochemical processes have been included in the scale-adaptive water transport scheme, which specifically addresses the small-river processes aligned with the advanced features of the water transport scheme (Yao et al., 2020).

The advective transport of $\mathrm{N}$ through the subnetwork combines inputs from hillslope flow and groundwater, which can be expressed as:

$$
\begin{gathered}
F_{x, \text { sub }}=Q_{\text {hill }} c_{x, \text { hill }}+Y_{x, \text { groundwater }}-Q_{\text {sub }} c_{x, \text { sub }} \\
Y_{x, \text { groundwater }}=\operatorname{Leach~}_{x, \text { veg }} \text { Area }_{\text {veg }}
\end{gathered}
$$


where $F_{x \text {,sub }}$ is advective $\mathrm{N}$ transport in subnetwork flow $\left(\mathrm{g} \mathrm{N} \mathrm{d}^{-1}\right), Q_{\text {hill }}$ and $Q_{\text {sub }}$ are flow rates of hillslope flow and subnetwork flow $\left(\mathrm{m}^{3} \mathrm{~s}^{-1}\right)$, respectively, $c_{x, \text { hill }}$ and $c_{x, \text { sub }}$ are concentrations $\left(\mathrm{mg} \mathrm{L}^{-1}\right)$ of $\mathrm{N}$ species $x$ in the hillslope flow and subnetworks, respectively; $Y_{x, \text { groundwater }}$ refers to the $\mathrm{N}$ derived from groundwater $\left(\mathrm{g} \mathrm{N} \mathrm{d}^{-1}\right)$, Leach $x$ is the land $\mathrm{N}$ leaching rate $\left(\mathrm{g} \mathrm{N} \mathrm{m}^{-2} \mathrm{~d}^{-1}\right)$ that varies with the plant function type (Gardner et al., 2016), and Area $\mathrm{veg}_{\mathrm{ve}}$ is the vegetation area for each plant function type $\left(\mathrm{m}^{2}\right)$.

The advective $\mathrm{N}$ flux through the main river channel is given as:

$$
F_{x, \text { main }}=\sum_{i=1}^{n} Q_{\mathrm{up}, i} c_{x, \mathrm{up}, i}+Q_{\mathrm{sub}} c_{x, \mathrm{sub}}-Q_{\mathrm{main}} c_{x, \text { main }}
$$

where $F_{x, \text { main }}$ is advective $\mathrm{N}$ transport in main channel flow $\left(\mathrm{g} \mathrm{N} \mathrm{d}^{-1}\right), Q_{\mathrm{up}, i}$ and $Q_{\text {main }}$ are the flow rates of upstream grid cell $i$ and the main channel in the current grid cell $\left(\mathrm{m}^{3} \mathrm{~s}^{-1}\right)$, respectively, and $c_{x, \text { up }, i}$ and $c_{x, \text { main }}$ are the associated $\mathrm{N}$ concentrations $\left(\mathrm{mg} \mathrm{L}^{-1}\right)$.

The major within-stream $\mathrm{N}$ dynamics include lateral $\mathrm{N}$ transport, mineralization of organic matter, particle organic matter deposition, nitrification, and denitrification. The calculations of these biochemical processes were improved based on original version of DLEM (Yang, Tian, Friedrichs, et al., 2015). Riverine N dynamics were calculated during both subnetwork flow and main channel flow. The conservation equations for the riverine $\mathrm{N}$ constituents are:

$$
\begin{gathered}
\frac{\Delta M_{\mathrm{PON}}}{\Delta t}=F_{\mathrm{PON}}+v_{s} A_{s} c_{\mathrm{PON}}-R_{\mathrm{PON}} M_{\mathrm{PON}} \\
\frac{\Delta M_{\mathrm{DON}}}{\Delta t}=F_{\mathrm{DON}}-R_{\mathrm{DON}} M_{\mathrm{DON}} \\
\frac{\Delta M_{\mathrm{NO} 3}}{\Delta t}=F_{\mathrm{NO} 3}+k_{n} V c_{\mathrm{NH} 4}-k_{d} V c_{\mathrm{NO} 3} \\
\frac{\Delta M_{\mathrm{NH} 4}}{\Delta t}=F_{a, \mathrm{NH} 4}+R_{\mathrm{DON}} M_{\mathrm{DON}}+R_{\mathrm{PON}} M_{\mathrm{PON}}-k_{n} V c_{\mathrm{NH} 4}+k_{d} V c_{\mathrm{NO} 3}
\end{gathered}
$$

where $M_{x}$ is the total mass of constituent $x\left(\mathrm{PON}, \mathrm{DON}, \mathrm{NO}_{3}{ }^{-}, \mathrm{NH}_{4}{ }^{+}\right.$) in the main channel or subnetwork ( $\mathrm{g}$ $\mathrm{N}), c_{x}$ is the concentration of $x$ in water body, $\Delta t$ is the time step, $F$ is advective $\mathrm{N}$ transport $\left(\mathrm{g} \mathrm{N} \mathrm{d}^{-1}\right), R_{\mathrm{DOM}}$ and $R_{\mathrm{PON}}$ are the mineralization rate coefficients of organic $\mathrm{N}\left(\mathrm{d}^{-1}\right), k_{n}$ and $k_{d}$ are the rates of nitrification and denitrification $\left(\mathrm{g} \mathrm{N} \mathrm{d}^{-1}\right)$, respectively, $V$ is the total volume of the water body $\left(\mathrm{m}^{3}\right)$, and $v_{s}$ is the deposition rate $\left(\mathrm{m} \mathrm{d}^{-1}\right)$.

The deposition velocity of particulate organic N is estimated by Stokes' law (Thomann \& Mueller, 1987):

$$
v_{s}=0.033634\left(\rho_{s}-\rho_{w}\right) d^{2}
$$

where $\rho_{s}$ and $\rho_{w}$ are the density of water and organic matter, respectively, and $d$ is the diameter of the organic matter.

The mineralization rate of the organic $\mathrm{N}$ is linearly correlated to the respiration rate of organic matter, which can be simulated by a first-order kinetics equation with temperature dependence:

$$
R_{\mathrm{DON}, \mathrm{PON}}=k_{m}\left(Q_{10}\right)^{\frac{T-T_{s}}{10}}
$$

where $k_{m}$ is the reduction rate $\left(\mathrm{m} \mathrm{d}^{-1}\right), Q_{10}$ is the change fraction of $\mathrm{N}$ reaction rates at a temperature change of $10^{\circ} \mathrm{C}, T$ is the water temperature $\left({ }^{\circ} \mathrm{C}\right)$, and $T_{s}$ is the reference temperature $\left(20^{\circ} \mathrm{C}\right)$. 
The inorganic $\mathrm{N}$ removal rate is estimated as:

$$
k_{d, n}=1-\exp \frac{-V_{f}}{H_{l}}
$$

where $V_{f}$ is the settling velocity for $\mathrm{N}$ species $\left(\mathrm{m} \mathrm{s}^{-1}\right)$, and $H_{l}$ is the hydraulic load $\left(\mathrm{m} \mathrm{s}^{-1}\right)$ for rivers and lakes, which can be expressed as:

$$
H_{l}=\frac{Q}{A_{s}}
$$

where $Q$ is discharge $\left(\mathrm{m}^{3} \mathrm{~s}^{-1}\right), A_{s}$ is the surface area of the water body $\left(\mathrm{m}^{2}\right)$, in which the surface area of the main channel was derived from remote sensing, and surface area of small streams was estimated as the product of the known stream length and the following empirical estimate of the width (Allen et al., 2018):

$$
\begin{gathered}
\text { width }=Q^{\frac{3}{5 r+3}}\left(0.5 A^{0.42}\right)_{i}^{\frac{r-1}{r+0.6}}\left(8.1(g S)^{0.5} k^{-\frac{1}{6}} 14^{-\frac{5}{3}}\left(1-\frac{1}{r+1}\right)\right)^{-\frac{3}{5 r+3}} \\
k=\left(8.1 g^{0.5} n\right)^{6}
\end{gathered}
$$

where $A$ is the upstream area (ha), $k$ is a bed roughness length scale, $r$ is a shape parameter, $g$ is the gravitational acceleration, $n$ is the Gauckler-Manning friction coefficient $\left(\mathrm{ms}^{-1 / 3}\right)$, and $S$ is the channel slope, which can be obtained from topographic data.

\subsection{Climate and Land-Use Forcings}

Environmental forcings that were used to drive DLEM included time-series of gridded data on atmospheric $\mathrm{CO}_{2}$ concentration, climate, land-use change, river network, and $\mathrm{N}$ inputs at a spatial resolution of $4 \mathrm{~km}$. The temporal variability of climate, land-use change, and $\mathrm{N}$ inputs are shown in Figure 3.

Atmospheric $\mathrm{CO}_{2}$ concentration was obtained from the NOAA GLOBALVIEW- $\mathrm{CO}_{2}$ data set (https://www. esrl.noaa.gov). The grid-based climate input data were derived from Parameter-elevation Relationships on Independent Slopes Model daily climate data sets (i.e., temperature and precipitation), which were obtained from http://www.prism.oregonstate.edu/. Mean annual ( \pm 1 standard deviation) precipitation and temperature during 1900-2015 in the $\mathrm{CBW}$ were $1,070 \pm 128 \mathrm{~mm}$ and $10.7^{\circ} \mathrm{C} \pm 0.6^{\circ} \mathrm{C}$, respectively. The precipitation and temperature both started to increase in the $1960 \mathrm{~s}$ with a rate of $3.29 \mathrm{~mm} \mathrm{yr}^{-1}$ for precipitation and $0.017^{\circ} \mathrm{C} \mathrm{yr}^{-1}$ for temperature.

Historical land-use change data were reconstructed based on multiple data sources, including county-level cropland area data (Waisanen \& Bliss, 2002) and the National Land Cover Database (https://www.mrlc.gov/ data). The cropland in this region decreased sharply since 1900, and by 1950, around $58 \%$ of it was converted to forest, grassland, and urban area. Forest increased $11 \%$ and urban area increased six-fold during 19002015. During recent decades, the rates of land-use change has decreased, especially for forest and cropland.

\subsection{Nitrogen Inputs}

The reconstructed $\mathrm{N}$ input data sets include atmospheric $\mathrm{N}$ deposition, synthetic $\mathrm{N}$ fertilizer application, $\mathrm{N}$ manure production, and wastewater N release from 1900 to 2015.

The county-level $\mathrm{N}$ deposition data, including reduced $\left(\mathrm{NH}_{x}\right)$ and oxidized $\left(\mathrm{NO}_{y}\right)$ forms during 1985-2014, were obtained from the Chesapeake Bay Program (2017). Assuming N deposition in 1985 from the CBP as the baseline, we reconstructed the $\mathrm{N}$ deposition data before 1985 using the temporal pattern in global $\mathrm{N}$ dep- 

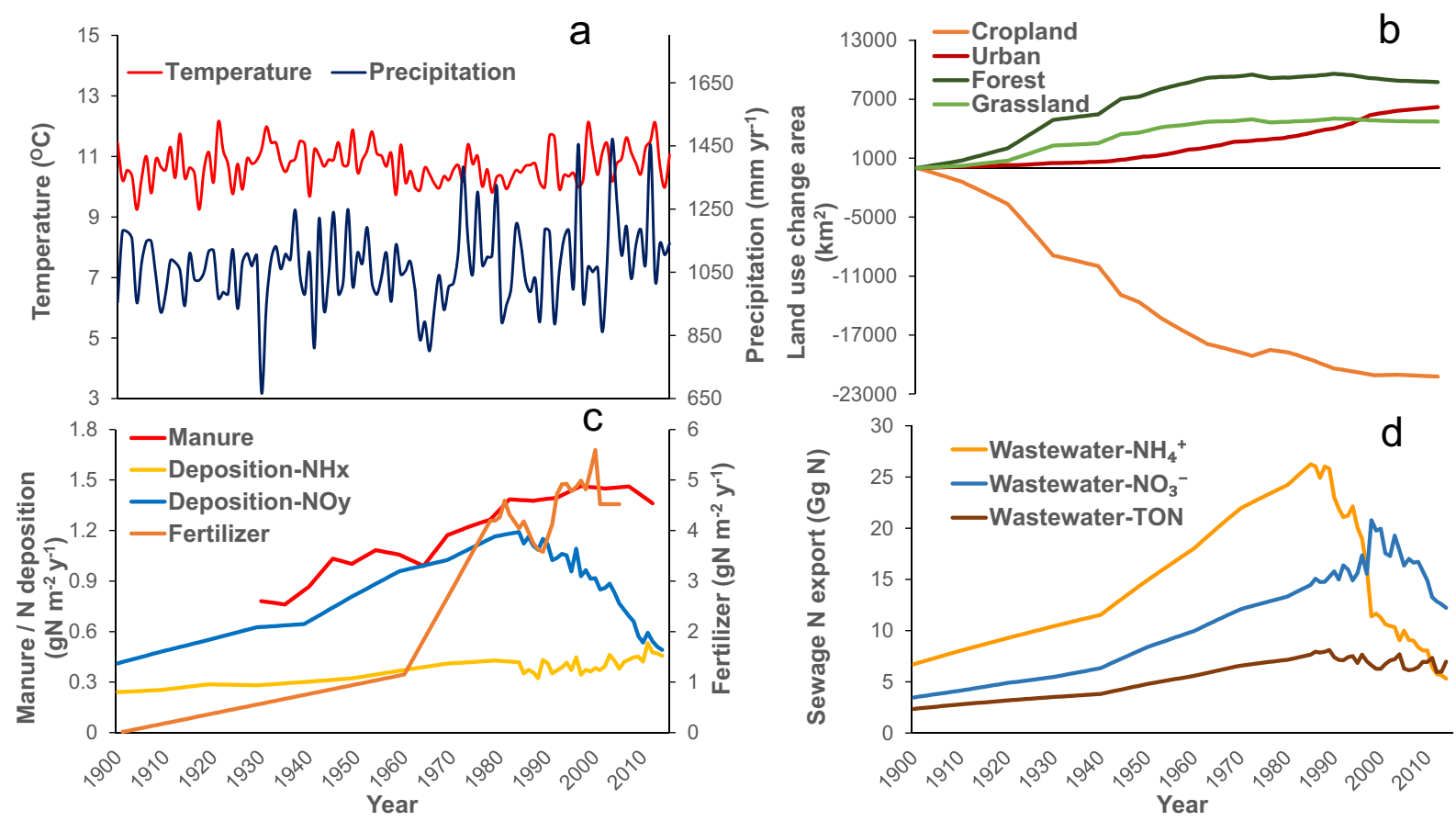

Figure 3. Temporal pattern of input data for driving DLEM: (a) climate variability and change; (b) changes in land use; (c) changes in N deposition, fertilizer use, and manure use; and (d) wastewater discharge.

osition (Dentener, 2006). Before the 1980s, the estimated atmospheric $\mathrm{NO}_{y}$ deposition increased dramatically, then decreased substantially from 1980 to 2014, while $\mathrm{NH}_{x}$ deposition slightly increased during the study period (Figure 3c). Crop-specific N application rates were derived from the National Agricultural Statistics Service (https://quickstats.nass.usda.gov/), and the annual total fertilizer application was calculated and adjusted according to the data from the Food and Agriculture Organization and the US Department of Agriculture. Then, we spatialized census fertilizer data based on cropland area (Klein Goldewijk et al., 2017) and harvest area (Portmann et al., 2010) maps, and more details regarding the development of gridded fertilizer data can be found in supporting information. The N manure production data during 1930-2012 were derived from the county-level livestock manure $\mathrm{N}$ production data set (Yang, Tian, Li, et al., 2016). Both time series of fertilizer and manure $\mathrm{N}$ data cannot cover the entire period of 1900-2015, so we assumed that these variables did not change before or after data-available period. Since 1980, the increasing trends of synthetic fertilizer and manure became slight with annual fluctuations superimposed (Figure 3c). Wastewater N release data during 1985-2014 were also obtained from the Chesapeake Bay Program (2017) and included industrial wastewater discharge, municipal wastewater discharge, and combined sewer overflows. The change rates of the wastewater $\mathrm{N}$ release before 1985 were estimated according to a statistically based approach that used population and gross domestic production to quantify the $\mathrm{N}$ consumption from food (Van Drecht et al., 2009). (Population \& GDP data source: ISIMIP2b, available at: https://www.isimip. org/.) We constructed wastewater $\mathrm{N}$ release from 1900 to 1984 by applying the calculated change rates on wastewater $\mathrm{N}$ data in 1985 . The $\mathrm{N}$ fluxes from wastewater decreased substantially, by $80 \%$ in $\mathrm{NH}_{4}{ }^{+}, 15 \%$ in $\mathrm{NO}_{3}{ }^{-}$, and 9\% in total organic nitrogen (TON), from 1985 to 2014 (Figure 3d).

\subsection{Model Evaluation}

The observed water quality data derived from the US Geological Survey (USGS) were processed by LOAD ESTimator (LOADEST), which is well recognized as the reference estimator for monthly $\mathrm{N}$ loadings (Runkel et al., 2004; Zhu et al., 2019). In general, the DLEM-simulated results were in good agreement with LOADEST estimates. The long-term annual average $\mathrm{N}$ loadings in six major rivers are well captured by DLEM (Table 1). The square of the correlation coefficient $\left(R^{2}\right)$ and Nash-Sutcliffe efficiency (NSE) were further used to evaluate the accuracy of the simulated results (McCuen et al., 2006) (Figure S1). The closer the $R^{2}$ 
Table 1

Annual Average N Loadings Estimated by DLEM and LOADEST

\begin{tabular}{|c|c|c|c|c|c|c|c|}
\hline \multirow[b]{2}{*}{ Rivers } & \multirow[b]{2}{*}{ Period } & \multicolumn{2}{|c|}{$\mathrm{NH}_{4}^{+}\left(\mathrm{Gg} \mathrm{N} \mathrm{yr}^{-1}\right)$} & \multicolumn{2}{|c|}{$\mathrm{NO}_{3}^{-}\left(\mathrm{Gg} \mathrm{N} \mathrm{yr}^{-1}\right)$} & \multicolumn{2}{|c|}{$\mathrm{TON}\left(\mathrm{Gg} \mathrm{N} \mathrm{yr}^{-1}\right)$} \\
\hline & & DLEM & LOADEST & DLEM & LOADEST & DLEM & LOADEST \\
\hline Susquehanna & 1979-2015 & 3.18 & 2.99 & 44.12 & 47.76 & 16.07 & 15.70 \\
\hline James & 1979-2015 & 0.23 & 0.29 & 3.47 & 2.43 & 3.10 & 2.67 \\
\hline Rappahannock & 1980-2015 & 0.07 & 0.10 & 1.90 & 1.18 & 0.84 & 0.74 \\
\hline Patuxent & 1979-2015 & 0.03 & 0.09 & 0.67 & 0.60 & 0.20 & 0.23 \\
\hline Potomac & 1979-2015 & 0.57 & 0.70 & 22.49 & 18.74 & 7.11 & 7.44 \\
\hline York & $1980-2015$ & 0.02 & 0.04 & 0.32 & 0.25 & 0.32 & 0.32 \\
\hline
\end{tabular}

Note. The USGS Gauge Stations selected for model evaluation were 01578310 (Susquehanna), 02035000 (James), 01668000 (Rappahannock), 01594440 (Patuxent), 01646580 (Potomac), and 01673000 (York).

and NSE are to 1, the higher the degree of agreement between the simulated estimates and the observations. For $\mathrm{NH}_{4}{ }^{+}$loading, the $R^{2}$ ranged from 0.15 to 0.54 and NSE ranged from -0.08 to 0.42 . For $\mathrm{NO}_{3}{ }^{-}, R^{2}$ values ranged from 0.53 to 0.70 and NSE values ranged from 0.31 to 0.62 . The model behaved well in simulating inorganic $\mathrm{N}$ in large sub-basins (e.g., Susquehanna, James, and Potomac), but the accuracy in simulating small sub-basins (e.g., Patuxent) is relatively low. Due to the scarcity of estuarine PON data at the USGS sites, the TON was used to evaluate model performance in simulating the combined DON and PON exports. The $R^{2}$ values and NSE values ranged from 0.33 to 0.45 and 0.31 to 0.42 , respectively, showing the reliability of the model in simulating TON in the major river basins. Target diagrams (Jolliff et al., 2009) between the DLEM and LOADEST results were also computed to evaluate the performance of the model (the closer the points are to the origin, the better the model performs, Figure S2). The simulated $\mathrm{NH}_{4}{ }^{+}$loadings were underestimated while simulated $\mathrm{NO}_{3}{ }^{-}$loadings were overestimated in 5 major rivers (except Susquehanna). The performance of the model in simulating TON was similar in all six rivers and included a slight bias.

\subsection{Factorial Simulation Experimental Design}

Eight simulation experiments were designed to investigate $\mathrm{N}$ export in response to multiple environmental factors (Table 2). The standard simulation (S0) represents the simulation based on all time-series data sets as input drivers. Seven additional simulation experiments were designed to keep one factor constant at the 1900 level and allowing other factors to change with time. Climate, $\mathrm{CO}_{2}$ concentration, $\mathrm{N}$ deposition, $\mathrm{N}$ manure, land-use change, $\mathrm{N}$ fertilizer, and $\mathrm{N}$ wastewater were kept constant with the initial year in simulations S1, S2, S3, S4, S5, S6, and S7, respectively. The contribution of each factor to N export could be separated by comparing the difference between $\mathrm{S} 0$ and the other experimental simulations.

Table 2

Designs of Factorial Experiments

\begin{tabular}{lccccccc}
\hline Experiments & Climate & $\mathrm{CO}_{2}$ & Atm. N deposition & N manure & Land use & N fertilizer & Wastewater \\
\hline S0 & $1900-2015$ & $1900-2015$ & $1900-2015$ & $1900-2015$ & $1900-2015$ & $1900-2015$ & $1900-2015$ \\
S1 & 1900 & $1900-2015$ & $1900-2015$ & $1900-2015$ & $1900-2015$ & $1900-2015$ & $1900-2015$ \\
S2 & $1900-2015$ & 1900 & $1900-2015$ & $1900-2015$ & $1900-2015$ & $1900-2015$ & $1900-2015$ \\
S3 & $1900-2015$ & $1900-2015$ & 1900 & $1900-2015$ & $1900-2015$ & $1900-2015$ & $1900-2015$ \\
S4 & $1900-2015$ & $1900-2015$ & $1900-2015$ & 1900 & $1900-2015$ & $1900-2015$ & $1900-2015$ \\
S5 & $1900-2015$ & $1900-2015$ & $1900-2015$ & $1900-2015$ & 1900 & $1900-2015$ & $1900-2015$ \\
S6 & $1900-2015$ & $1900-2015$ & $1900-2015$ & $1900-2015$ & $1900-2015$ & 1900 & $1900-2015$ \\
S7 & $1900-2015$ & $1900-2015$ & $1900-2015$ & $1900-2015$ & $1900-2015$ & $1900-2015$ & 1900 \\
\hline
\end{tabular}



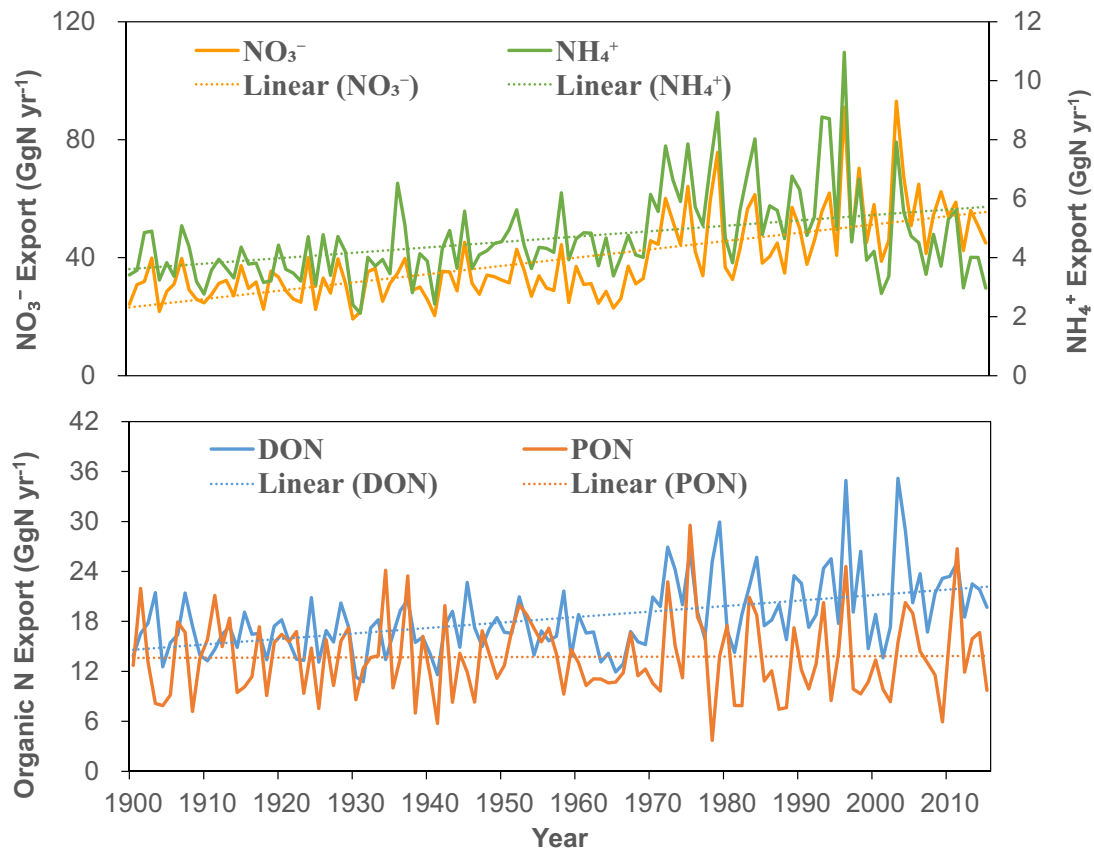

Figure 4. Annual averages of DLEM-simulated $\mathrm{N}$ export for four species $\left(\mathrm{NH}_{4}{ }^{+}, \mathrm{NO}_{3}{ }^{-}\right.$, DON, and PON) during 1900-2015. (Note the different vertical scales).

\section{Results}

\subsection{Long-Term Change in $\mathrm{N}$ Loading (1900-2015)}

The simulated $\mathrm{N}$ export shows that during 1900-2015, the inorganic $\mathrm{N}$ export $\left(\mathrm{NH}_{4}{ }^{+}\right.$and $\left.\mathrm{NO}_{3}{ }^{-}\right)$accounted for $72 \%$ of the total N (TN) export from the CBW (Figure 4). The temporal patterns of export of the two inorganic $\mathrm{N}$ species were similar to each other, but $\mathrm{NO}_{3}{ }^{-}$dominated, contributing $94 \%$ of the total inorganic $\mathrm{N}$ flux. Average simulated riverine fluxes of $\mathrm{NH}_{4}{ }^{+}$and $\mathrm{NO}_{3}{ }^{-}$for 1900-2015 were 5.12 and $79.8 \mathrm{Gg} \mathrm{N} \mathrm{y}^{-1}$. We also compare three time periods to each other: 1900 to 1909 (the "1900s"), 1990 to 1999 (the "1990s"), and 2010 to 2015. Decadal averages of export from the 1900s to the 1990 s changed from 4.4 to $7.2 \mathrm{Gg} \mathrm{N} \mathrm{y}^{-1}$ for $\mathrm{NH}_{4}{ }^{+}$(increase of $66 \%$ ) and 51.0 to $113.6 \mathrm{Gg} \mathrm{N} \mathrm{y}^{-1}$ for $\mathrm{NO}_{3}{ }^{-}$(increase of 123\%). Export averages during 2010-2015 were $4.87 \mathrm{Gg} \mathrm{N} \mathrm{y}^{-1}$ for $\mathrm{NH}_{4}{ }^{+}$and $98.0 \mathrm{Gg} \mathrm{N} \mathrm{y}^{-1}$ for $\mathrm{NO}_{3}{ }^{-}$, decreases of $32 \%$ and $14 \%$, respectively, compared to the 1990 s averages.

The estimated TON export (DON and PON) accounted for $28 \%$ of the TN export from the CBW during 1900-2015. The exports of the two organic N species were similar, with DON accounting for 57\% (19.1 Gg $\mathrm{N} \mathrm{y}^{-1}$ ) and PON accounting for $43 \%\left(14.2 \mathrm{Gg} \mathrm{N} \mathrm{y}^{-1}\right.$ ) of the TON export. Similar to the inorganic $\mathrm{N}$ species, average export of DON increased from the 1900s $\left(16.7 \mathrm{Gg} \mathrm{N} \mathrm{y}^{-1}\right)$ to the $1990 \mathrm{~s}\left(23.4 \mathrm{Gg} \mathrm{N} \mathrm{y}^{-1}\right)$ and then decreased from the $1990 \mathrm{~s}$ to $2010-2015\left(22.0 \mathrm{Gg} \mathrm{N} \mathrm{y}^{-1}\right)$. Unlike the temporal pattern of the other three $\mathrm{N}$ species, PON export was relatively stable, with averages of 12.9, 13.7, and $17.0 \mathrm{Gg} \mathrm{N} \mathrm{y}^{-1}$ during the 1900s, 1990s, and 2010-2015, respectively.

The Susquehanna, Potomac, and James Rivers have considerably larger sub-basins than the other three rivers (i.e., Rappahannock, York, and Patuxent) (Figure 1a). The larger the area of the river sub-basin, the higher the TN export of the river (Figure S3). The average estimated riverine fluxes of TN during 1900-2015 were 52.0, 25.7, and 5.5 Gg N y ${ }^{-1}$ in the Susquehanna, Potomac, and James Rivers, respectively. The interannual variations in TN export in the three rivers were similar. The coefficients of variation (standard deviation/mean) of the three rivers were all around 30\%, which indicated similar interannual variability. $\mathrm{NO}_{3}{ }^{-}$ was the dominant contributor to the TN export in the Susquehanna River (66\%) and in the Potomac River (72\%). For the James River, $\mathrm{NO}_{3}{ }^{-}(46 \%)$ and TON (51\%) contributed similarly to the TN export. We found that $\mathrm{NO}_{3}{ }^{-}$dominated the $\mathrm{TN}$ export change in all the three rivers in the CBW, especially after the 1970s, when the portions of TON and $\mathrm{NH}_{4}{ }^{+}$in TN decreased significantly due to the substantial increase in $\mathrm{NO}_{3}{ }^{-}$. 

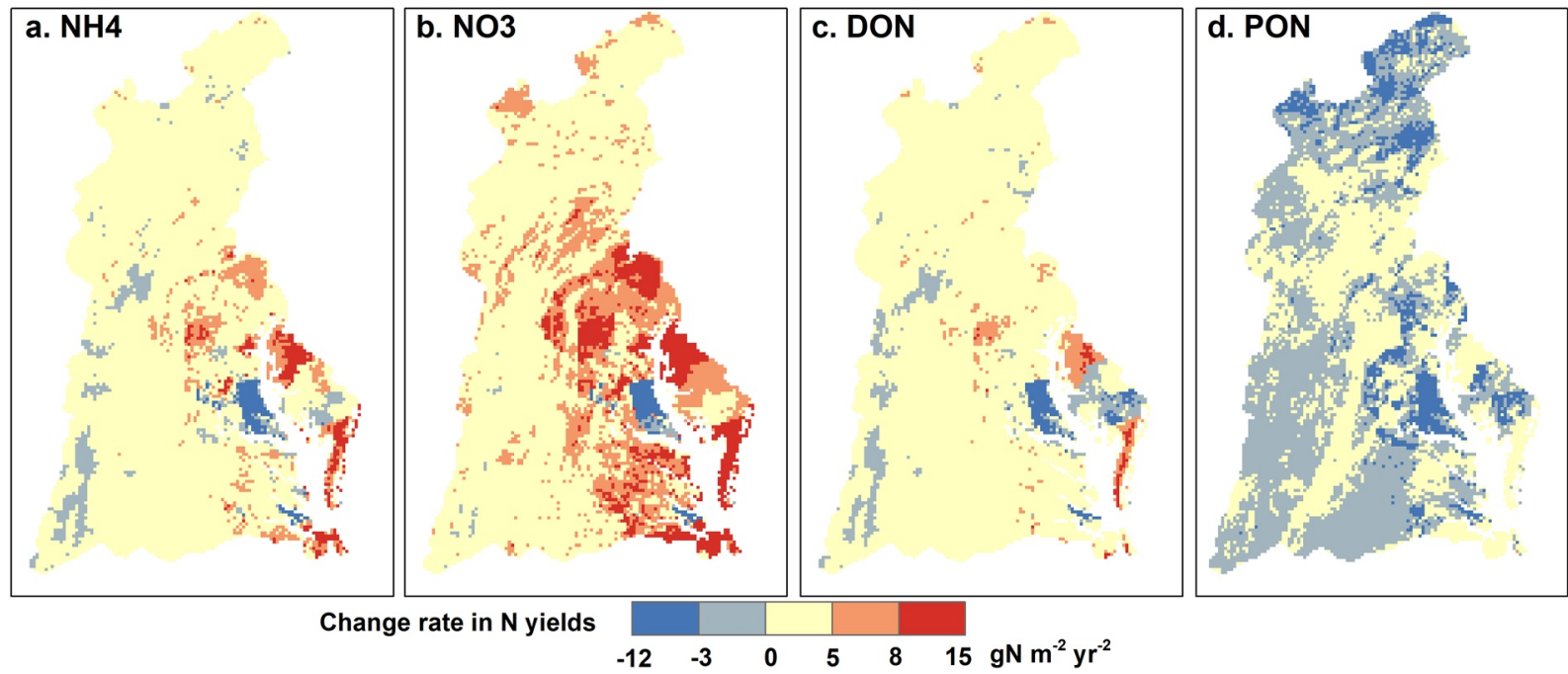

Change rate in $\mathrm{N}$ yields

$\begin{array}{llllll}-12 & -3 & 0 & 5 & 8 & 15 \mathrm{gN} \mathrm{m}^{-2} \mathrm{yr}^{-2}\end{array}$

Figure 5. Spatial distributions of long-term changes (1900-2015) in $\mathrm{N}$ yield: (a) $\mathrm{NH}_{4}{ }^{+}$, (b) $\mathrm{NO}_{3}{ }^{-}$, (c) $\mathrm{PON}$, and (d) DON.

\subsection{Spatial Variability of $\mathbf{N}$ Yield Changes}

Trends of changes in $\mathrm{N}$ yield fluxes from land to rivers (Equations 1 and 2) were calculated based on the Mann-Kendall test with a 95\% confidence level. The spatial patterns of these long-term changes in $\mathrm{N}$ yield rates differed among the four $\mathrm{N}$ species (Figure 5). The estimated yield rates of $\mathrm{NH}_{4}{ }^{+}$increased during 1900-2015 in most of the watershed, with several hotspots in cropland and urban area (Figures 5a and 1b). Increases in yield rate of $\mathrm{NO}_{3}{ }^{-}$was much higher in terms of magnitude. Changes in yield rates of $\mathrm{NO}_{3}{ }^{-}$in the southeastern part of the watershed near the Chesapeake Bay were higher than those in the western part, with the exception of the areas north of the Potomac and Patuxent Rivers and between the James and York Rivers. The yield rates increased significantly (8-15 $\mathrm{g} \mathrm{N} \mathrm{m}^{-2} \mathrm{y}^{-2}$ ) on cropland, urban area, and wetland (Figures 5b and 1b). Although DON yield rates increased throughout most of the watershed, the annual change in yield rate was generally small $\left(0-5 \mathrm{~g} \mathrm{~N} \mathrm{~m}^{-2} \mathrm{y}^{-2}\right.$ ) (Figure $5 \mathrm{c}$ ). PON yield rates demonstrated opposite trends in different parts of the watershed. Decreased PON yield rates mainly occurred along the northern and southern margins of the watershed, while increased PON yield rates occurred in the central part (Figure 5d). One noteworthy region was the Patuxent sub-basin and part of the Potomac sub-basin adjacent to the bay, where the yield rates of $\mathrm{NO}_{3}{ }^{-}, \mathrm{NH}_{4}{ }^{+}, \mathrm{DON}$, and $\mathrm{PON}$ all clearly decreased (changes of -12 to $-3 \mathrm{~g} \mathrm{~N} \mathrm{~m}^{-2} \mathrm{y}^{-2}$ ).

\subsection{Contributions of Multiple Environmental Factors to Changes in Riverine N Fluxes}

Long-term variability in the export of different $\mathrm{N}$ species was driven by different environmental factors (Figure 6). The change in $\mathrm{NH}_{4}{ }^{+}$export was dominated by change in wastewater discharge (Figure 6a). The impact of wastewater discharge is especially noticeable in the 1980s, when the standard simulation (S0) had an export of $\mathrm{NH}_{4}{ }^{+}$that was $80 \%$ higher than the "constant wastewater" simulation (S7) (Table 1). However, averaged over 2010-2015, export of $\mathrm{NH}_{4}{ }^{+}$in S0 was higher than that in S7 by only 5\%. Atmospheric $\mathrm{N}$ deposition played a more important role in enhancing riverine $\mathrm{NH}_{4}^{+}$than other factors during 2010-2015. Nitrogen export over 2010-2015 in S0 was 11\% higher compared to that in S3 (constant N deposition). During most of the historical period, climatic variability decreased $\mathrm{NH}_{4}{ }^{+}$export, especially in two dry periods: the 1960s (-22\%) and the 1980s (-15\%). Land-use change (LUC) caused the largest decrease of $\mathrm{NH}_{4}{ }^{+}$export in the latter half of the twentieth century, and $\mathrm{NH}_{4}{ }^{+}$export in $\mathrm{S} 0$ was $18 \%$ lower than the "constant LUC" simulation (S5) during 2010-2015.

Long-term variability of riverine $\mathrm{NO}_{3}{ }^{-}$was mainly due to synthetic $\mathrm{N}$ fertilizer use, atmospheric $\mathrm{N}$ deposition, and LUC (Figure 6b). From the 1900s to the 1960s, atmospheric N deposition increased decadal averages of $\mathrm{NO}_{3}{ }^{-}$export by $19 \%$. Since the 1970 s, synthetic $\mathrm{N}$ fertilizer use became the largest contributor to $\mathrm{NO}_{3}{ }^{-}$export. Averaged export of $\mathrm{NO}_{3}{ }^{-}$over 2010-2015 in S0 was higher than that in "constant $\mathrm{N}$ fertilizer" 


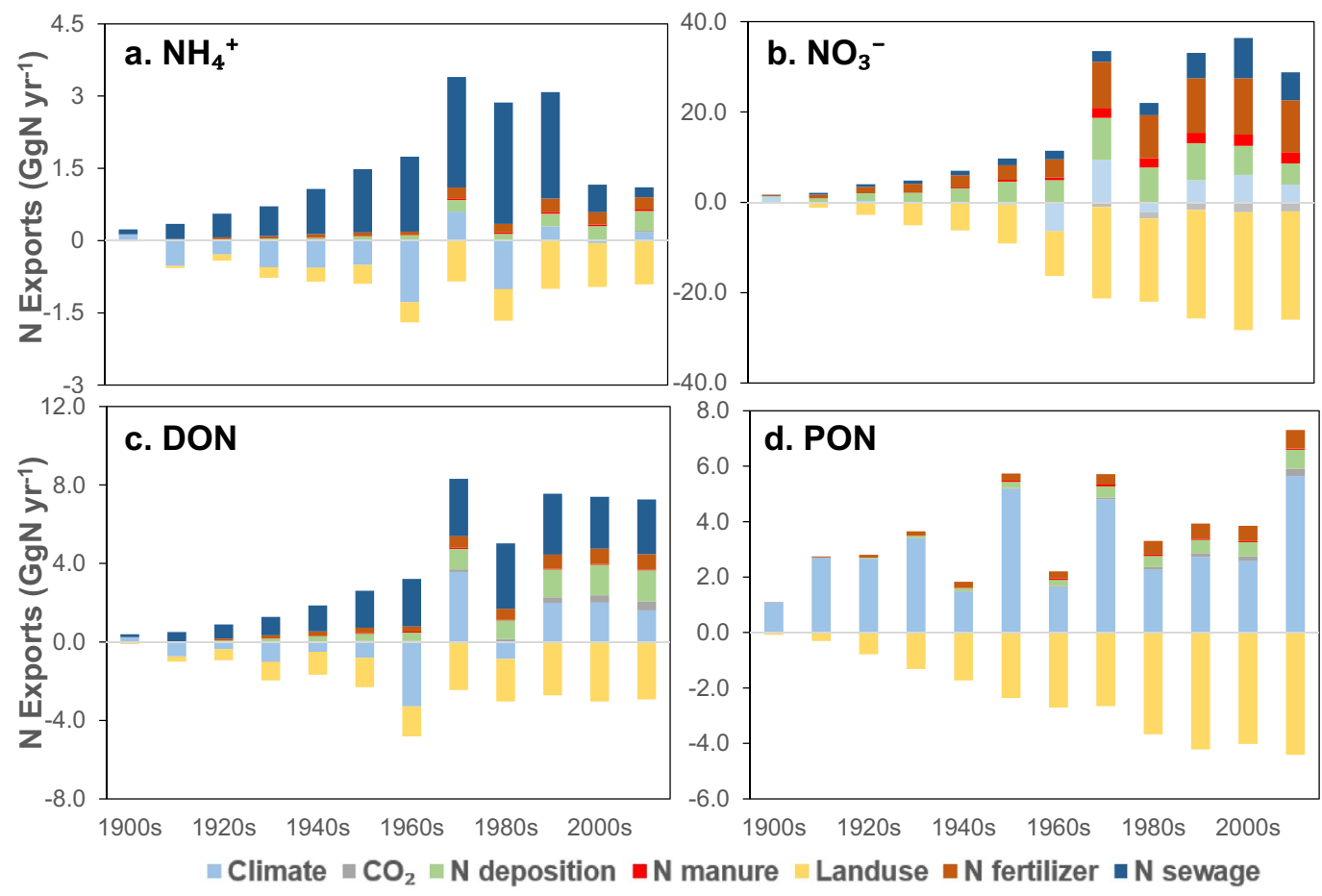

Figure 6. Relative contributions of individual environmental factors to changes in average riverine $\mathrm{N}$ fluxes: (a) $\mathrm{NH}_{4}{ }^{+}$, (b) $\mathrm{NO}_{3}^{-}$, (c) DON, and (d) PON. All averages are decadal, except for the last set of bars, in which the averaging period is $2010-2015$.

simulation (S6) and "constant $\mathrm{N}$ deposition" simulation (S3) by $29 \%$ and 10\%, respectively. LUC decreased $\mathrm{NO}_{3}{ }^{-}$export over the study period, and the difference between the S0 and S5 increased with anthropogenic $\mathrm{N}$ inputs (atmospheric $\mathrm{N}$ deposition, animal manure, and synthetic $\mathrm{N}$ fertilizer) (Figure 6b).

Similar to $\mathrm{NH}_{4}{ }^{+}$, DON export change was largely attributable to the change in wastewater discharge (Figure 6c). In the 1980s, DON export was enhanced by $21 \%$ in S0 compared with S7. Climate variability reduced the DON flux before the 1960s and generally increased the DON flux after the 1970s. LUC caused a decrease in DON flux during the whole period, while the increase of $\mathrm{N}$ inputs (i.e., atmospheric $\mathrm{N}$ deposition, animal manure, and synthetic $\mathrm{N}$ fertilizer) enhanced the DON flux.

Export of PON was controlled by two opposite impacts derived from LUC and climate (Figure 6d). Climate variability had a positive impact on PON export, increasing the average export by more than $40 \%$ in the 1950s, 1970s, and during 2010-2015 compared with that in "constant climate simulation" (S1). LUC, however, had a negative impact on PON export. For example, after the 1980s, PON export decreased by around $20 \%$ as a result of LUC.

When considering the impact of multiple driving forces on TN export, it should be noted that the dominant factor varies during different decades (Table 3). From the 1930s to the 1960s, atmospheric N deposition was the primary factor that increased the TN export. A more than decade long drought was broken in the 1970s, with higher precipitation enhancing TN export by $18.4 \mathrm{Gg} \mathrm{N} \mathrm{yr}^{-1}$. This included record floods from tropical storm Agnes. During 1980-2015, synthetic fertilizer became the most important contributor, enhancing TN export by over $10 \mathrm{Gg} \mathrm{N} \mathrm{yr}^{-1}$. LUC was the major factor that decreased TN export, and the LUC-caused reduction of TN export increased from $0.4 \mathrm{Gg} \mathrm{N} \mathrm{yr}^{-1}$ in the 1900 s to $32.2 \mathrm{Gg} \mathrm{N} \mathrm{yr}^{-1}$ during 2010-2015. In each decade of the study period, the difference between S0 and S5 (land use) balanced the sum of the differences between $\mathrm{S} 0$ and the other four factorial experiments with constant anthropogenic N inputs: S3 (atmospheric $\mathrm{N}$ deposition), S4 ( $\mathrm{N}$ manure), S6 ( $\mathrm{N}$ fertilizer), and S7 ( $\mathrm{N}$ wastewater). 
Table 3

Decadal Changes in the Difference of TN Export between the Standard Simulation (SO) and Factorial Experiments (S1-S7)

\begin{tabular}{lccccccc}
\hline Decade & S1 (climate) & S2 $\left(\mathrm{CO}_{2}\right)$ & $\begin{array}{c}\mathrm{S} 3(\mathrm{~N} \\
\text { deposition })\end{array}$ & $\begin{array}{c}\mathrm{S} 4(\mathrm{~N} \\
\text { manure })\end{array}$ & $\begin{array}{c}\text { S5 (land } \\
\text { use })\end{array}$ & $\begin{array}{c}\text { S6 }(\mathrm{N} \\
\text { fertilizer })\end{array}$ & $\begin{array}{c}\mathrm{S} 7(\mathrm{~N} \\
\text { wastewater })\end{array}$ \\
\hline $1900 \mathrm{~s}$ & 2.7 & 0.0 & 0.1 & 0.0 & -0.4 & 0.2 & 0.4 \\
$1910 \mathrm{~s}$ & 1.4 & 0.0 & 0.9 & 0.0 & -1.8 & 0.9 & 1.1 \\
$1920 \mathrm{~s}$ & 2.3 & 0.0 & 1.8 & 0.0 & -4.2 & 1.6 & 1.8 \\
$1930 \mathrm{~s}$ & 1.6 & 0.0 & 2.4 & 0.0 & -7.3 & 2.4 & 2.3 \\
$1940 \mathrm{~s}$ & 0.2 & 0.1 & 3.5 & 0.3 & -9.2 & 3.2 & 3.3 \\
$1950 \mathrm{~s}$ & 3.3 & 0.1 & 5.3 & 0.5 & -12.9 & 3.8 & 4.7 \\
$1960 \mathrm{~s}$ & -9.2 & 0.0 & 5.6 & 0.7 & -14.6 & 4.5 & 5.9 \\
$1970 \mathrm{~s}$ & 18.4 & -0.8 & 11.0 & 2.3 & -26.3 & 11.3 & 7.6 \\
$1980 \mathrm{~s}$ & -1.8 & -1.2 & 9.2 & 2.2 & -24.9 & 10.7 & 8.5 \\
$1990 \mathrm{~s}$ & 10.0 & -1.3 & 10.3 & 2.5 & -31.9 & 13.6 & 10.9 \\
$2000 \mathrm{~s}$ & 10.6 & -1.7 & 8.7 & 2.7 & -34.0 & 14.1 & 12.2 \\
$2010-2015$ & 11.3 & -1.3 & 7.4 & 2.6 & -32.2 & 13.2 & 8.9 \\
\hline
\end{tabular}

Unit: $\mathrm{Gg} \mathrm{N} \mathrm{yr}{ }^{-1}$.

Note. The difference values indicate the contributions of environmental factors on TN export, and the higher the value, the greater the contribution.

\section{Discussion}

\subsection{Comparison With the Previous Studies}

Riverine $\mathrm{N}$ export is a critical driver of eutrophication and hypoxia in coastal waters. The riverine $\mathrm{N}$ flux from the CBW into the estuary, which is strongly regulated by anthropogenic activities, has received wide attention. The annual TN exports during 1985-2014 simulated by DLEM were compared with annual TN export simulated by the Phase 6.0 Watershed Model (CBP-Phase 6) as well as with the flow-normalized TN fluxes in 1992, 2002, and 2012 simulated by the spatially referenced regression model (SPARROW) (Ator, García, et al., 2019) (Figure 7). The magnitude and variation of riverine $\mathrm{N}$ flux from the CBW simulated by DLEM are in line with the other two models. The average annual $\mathrm{N}$ load estimated by CBP-Phase 6 was $142 \mathrm{Gg} \mathrm{N} \mathrm{y}^{-1}$ over 1985-2014, which was close to $149 \mathrm{Gg} \mathrm{N} \mathrm{y}^{-1}$ estimated by DLEM. The SPARROW results showed that the annual flow-normalized $\mathrm{N}$ flux declined by 14\% between 1992 and 2012, due primarily to reduced point sources. Similarly, the simulated N flux in this study declined 16\% during 1992-2012, largely

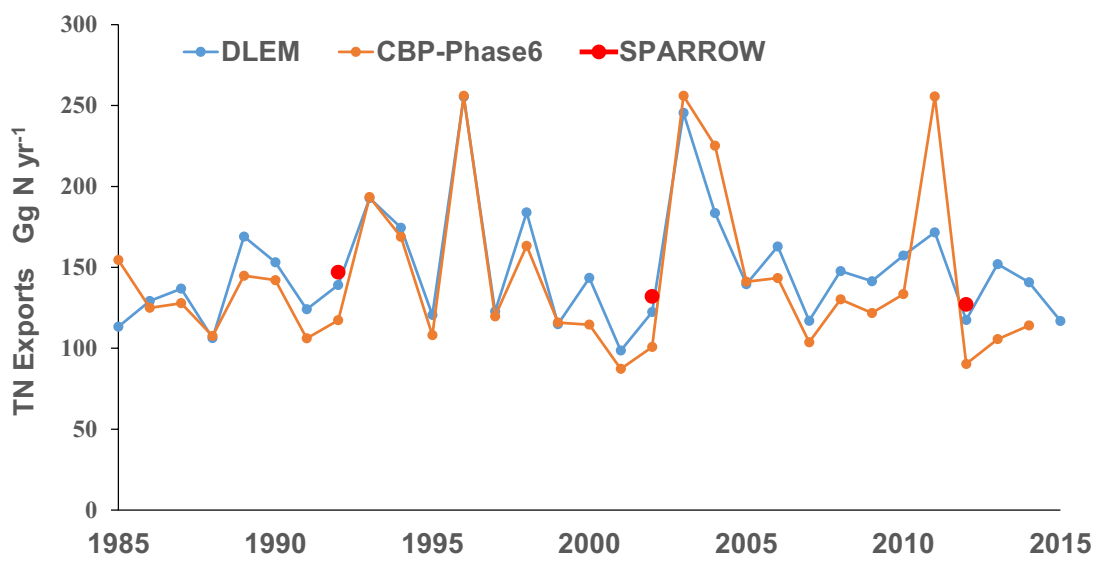

Figure 7. Comparison of TN export from the CBW simulated by DLEM, CBP-Phase 6, and SPARROW. 
as a result of the substantial reduction of $\mathrm{NH}_{4}{ }^{+}$in wastewater. The temporal pattern of TN exports simulated by DLEM is comparable with other previous estimates as well. The significant TN increase before the 1990s and moderate decrease thereafter simulated by DLEM is clearly evident in other studies (Harding, Gallegos, et al., 2016; Harding, Mallonee, et al., 2016; Scavia et al., 2006; Q. Zhang, Brady, et al., 2015).

In contrast to other studies, however, here we use a mechanistic model to examine nitrogen changes over the century scale and investigate the factors responsible for the spatiotemporal patterns of specific $\mathrm{N}$ species. The Chesapeake Bay Monitoring Program provides water quality data since 1984 and hence the numerous studies based on these data are limited to a shorter period of time, for example, 30 years (Prasad et al., 2010; Shields et al., 2008; Tango \& Batiuk, 2016). Since the interannual variability of N export is to first order dominated by interannual variations in precipitation and discharge, it can be difficult to identify the contributions of other factors over this time period. In this study, the changing trend of $\mathrm{N}$ loading at the century scale was presented and the impacts of multiple environmental factors were explored over this much longer historical period. Compared with CBP-Phase 6 and SPARROW, the process-based terrestrial ecosystem module of DLEM simulates the legacy $\mathrm{N}$ stored in soil, which contributes to the lag-time delivery of $\mathrm{N}$. In addition, riverine $\mathrm{N}$ was separated into four species in this study while many other studies just focused on $\mathrm{NO}_{3}{ }^{-}$or $\mathrm{TN}$, or only separated $\mathrm{N}$ into organic $\mathrm{N}$ and inorganic $\mathrm{N}$ components (Wang et al., 2016; Q. Zhang, Brady, et al., 2015). According to our study here, different N species display distinct trends and show a diversity of responses to multiple driving forces. Analyzing the variability of different $\mathrm{N}$ species can help us understand the potential reasons for the change in TN export, find the key contributing factors, and develop corresponding strategies for nutrient reduction.

\subsection{The Impacts of Multiple Drivers on $\mathrm{N}$ Export}

The rates and magnitudes of riverine $\mathrm{N}$ fluxes are influenced by multiple environmental factors, including climate variability, land-use change, and changes in $\mathrm{N}$ inputs. Nitrogen has been fixed from the atmosphere into the terrestrial ecosystem through biological, chemical, and industrial processes. Reactive $\mathrm{N}$ in various forms from different sources enters into the terrestrial $\mathrm{N}$ cycle and involves different biogeochemical processes. Atmospheric $\mathrm{N}$ deposition, the $\mathrm{N}$ in wastewater discharge, and the applications of $\mathrm{N}$ manure and synthetic $\mathrm{N}$ fertilizer to agricultural land are four important anthropogenic sources for riverine $\mathrm{N}$ exports (Ator, Blomquist, et al., 2020).

Climate not only influences the rates and magnitudes of chemical processes in $\mathrm{N}$ cycling but also dominates the hydrological processes that determine the amount of $\mathrm{N}$ entering into the river and finally into the estuary. The linear correlation coefficients between annual precipitation and estimated $\mathrm{NH}_{4}{ }^{+}, \mathrm{NO}_{3}{ }^{-}, \mathrm{DON}$, and PON exports are $0.60,0.62,0.75$, and 0.53 , respectively, which indicates that precipitation is the primary reason for the interannual variability of riverine $\mathrm{N}$ export, similar to the findings of other studies (Ballard et al., 2019; Sinha \& Michalak, 2016). High precipitation leads to high yield rates and high discharge, which decreases the residence time of $\mathrm{N}$ within a watershed. Nitrogen losses from denitrification, immobilization, and plant uptake processes also decrease with high yield rates (Donner et al., 2004; Howarth, Swaney, Boyer, et al., 2006). When water laterally and vertically flows in the soil, dissolved $\mathrm{N}$ species $\left(\mathrm{NH}_{4}{ }^{+}, \mathrm{NO}_{3}{ }^{-}\right.$, and DON) are more likely to follow the water into rivers compared to PON. In this study, TN export peaked in 1996 and 2003 when precipitation also peaked (Figures 4 and S3). Generally, extreme precipitation can enhance riverine $\mathrm{N}$ export through intensified surface wash-off and subsurface transport (Iqbal et al., 2018; Strickling \& Obenour, 2018). Conversely, the low TN exports in 1930, 1941, and 2001 were all associated with the lowest precipitation, which demonstrates the impact of extreme drought on $\mathrm{N}$ export. According to Strickling and Obenour (2018), nonpoint sources can export more nutrients during wet years, but some source types responded more strongly to precipitation than others. Therefore, the sensitivity of $\mathrm{N}$ export to anthropogenic inputs depends on precipitation.

In the CBW, cropland was converted to forest and grassland beginning in the 1900s, as farms were abandoned due primarily to economic conditions (Brush, 2009). The decreasing cropland area led to less soil N depletion and the forests that took over were much more N-retentive. As a result, this LUC reduced inorganic $\mathrm{N}$ export. Since forest typically has a lower soil erosion rate than cropland, less PON would enter into the rivers (Seitzinger et al., 2002). As the huge area of cropland was converted to forest in the Patuxent sub-basin and in part of the Potomac sub-basin, both organic $\mathrm{N}$ and inorganic $\mathrm{N}$ yield from terrestrial ecosystems 
substantially decreased (Figure 5). In this region, LUC-induced reduction in N export offsets the increase of N export due to atmospheric and agricultural N inputs. Since the 1970s, the conversion rate from cropland to forest and grassland started to decrease while urban area expanded rapidly, and atmospheric $\mathrm{N}$ deposition in urban areas was easily transported into aquatic systems through surface runoff. Thus, the negative effect of LUC on riverine $\mathrm{N}$ export became stable (for $\mathrm{PON}$ ) or decreased (for $\mathrm{NO}_{3}^{-}$) in recent decades.

In the mid-to-late 20th century, the CBW experienced rapid urbanization, with a rise of impervious area and population. High loads of wastewater were generated that were further enriched in $\mathrm{N}$ due to increasing levels of protein consumption (C. Liu et al., 2014; W. Zhang, Swaney et al., 2017). When untreated wastewater enters into river systems directly, $\mathrm{N}$ export increases considerably, especially for $\mathrm{NH}_{4}{ }^{+}$and DON. It is worth noting that after the 1980s, wastewater $\mathrm{N}$ started to decrease as a result of improved wastewater treatment systems. Harding, Gallegos, et al. (2016) and Harding, Mallonee, et al. (2016) provided evidence of significant progress in reducing point-source TN from 1985 to 2011, with declines of TN from 47.1 to 25.5 Gg N $\mathrm{yr}^{-1}$. Ator, García, et al. (2019) suggested that point-source reductions account for more than $80 \%$ of the decline in $\mathrm{N}$ flux to the Chesapeake Bay between 1992 and 2012. The reduction of $\mathrm{NH}_{4}{ }^{+}$in wastewater was higher than that for DON, so $\mathrm{NH}_{4}{ }^{+}$export decreased more significantly than DON export. However, it is not enough to control the $\mathrm{N}$ loading from wastewater since $\mathrm{NH}_{4}{ }^{+}$and $\mathrm{DON}$ only account for a small portion of $\mathrm{TN}$, and wastewater was not the major contributor to $\mathrm{NO}_{3}{ }^{-}$export. Therefore, in order to control TN in rivers, it is necessary to reduce nonpoint-source loadings as well.

Although cropland area in the CBW has decreased since 1900, the usage of manure and synthetic fertilizer has dramatically increased. Ammonium- and nitrate-based fertilizers are two major forms of synthetic $\mathrm{N}$ fertilizer (Havlin et al., 2016). When more fertilizer $\mathrm{N}$ is applied than the crops can incorporate, only a portion of the fertilizer can be absorbed by plants, leaving large amounts of fertilizer in the soil for yield during rainfall events (Poor \& McDonnell, 2007; Royer et al., 2006). Since $\mathrm{NH}_{4}{ }^{+}$is easily converted to $\mathrm{NO}_{3}{ }^{-}$through nitrification in the soil, fertilizer contributes more to riverine $\mathrm{NO}_{3}{ }^{-}$than to $\mathrm{NH}_{4}{ }^{+}$. The application of animal manure and synthetic $\mathrm{N}$ fertilizer facilitates plant growth, which results in increased crop residues in soils and ultimately contributes to more organic $\mathrm{N}$ in rivers. But the contributions of fertilizer $\mathrm{N}$ input on organic $\mathrm{N}$ species are lower than inorganic species because organic $\mathrm{N}$ is leached from relatively stable $\mathrm{N}$ pools in litter and soil organic matter (Goodale et al., 2000). Reducing the application of synthetic $\mathrm{N}$ fertilizer and simultaneously improving nitrogen-use efficiency could largely decrease riverine $\mathrm{NO}_{3}{ }^{-}$, the largest component of TN export to the Chesapeake Bay.

Decreased atmospheric $\mathrm{NO}_{\mathrm{y}}$ since the 1980s has been closely related to the Clean Air Act and its amendments. Du et al. (2014) suggested that wet $\mathrm{NO}_{\mathrm{y}}$ deposition decreased significantly at the national scale in the US since 1985, which was attributed to the curbing of $\mathrm{NO}_{y}$ emissions by the promulgation of the Clean Air Act and especially the 1990 amendments. Eshleman and Sabo (2016) demonstrated that reductions in atmospheric $\mathrm{N}$ emissions and deposition were the primary driver of declining nitrate-N yields across the Upper Potomac River Basin. However, atmospheric $\mathrm{NH}_{x}$ increased in recent decades due to elevated ammonia emissions from livestock wastes and synthetic $\mathrm{N}$ fertilizer application (Davidson et al., 2011; Reis et al., 2009). Atmospheric $\mathrm{NO}_{y}$ is one of the major contributors to the changes in riverine $\mathrm{NO}_{3}{ }^{-}$, and the reduction of atmospheric $\mathrm{NO}_{y}$ in recent decades thus decreased the riverine $\mathrm{NO}_{3}{ }^{-}$flux. Atmospheric $\mathrm{NH}_{x}$, on the other hand, has contributed more to riverine $\mathrm{NH}_{4}{ }^{+}$in recent years. The reductions of $\mathrm{NO}_{3}{ }^{-}$in atmospheric deposition and $\mathrm{NH}_{4}{ }^{+}$in wastewater both demonstrate the critical roles played by policy and the implementation of antipollution measures.

\subsection{Uncertainty}

Uncertainty in simulated $\mathrm{N}$ export in this study is mainly associated with model structure, parameterization, and input data. DLEM considers lateral fluxes of $\mathrm{N}$ through surface runoff and subsurface runoff as the key mechanism for $\mathrm{N}$ entering into rivers, but the model simplifies the transport of groundwater and the soil $\mathrm{N}$ exchange with groundwater, which is an important source of $\mathrm{N}$ for streams (Terziotti et al., 2018). Riverine $\mathrm{N}$ export is also influenced by dam construction and irrigation (Gergel et al., 2005; Gheysari et al., 2009), which are not considered in the current version of the model. It is also difficult for the model to accurately simulate runoff in small watersheds due to the huge impact of human activity on runoff variation. 
The input data, which include information on land-use, wastewater discharge, and the application of synthetic $\mathrm{N}$ fertilizer and animal manure, are not fully available for the whole 20th century. Therefore, these data were calculated and reconstructed based on statistical approaches before certain points in time, which leads to some uncertainty in the results for the early years of the 20th century. For example, the high wastewater input in the Patuxent basin during the early 1980s was not captured in the reconstructed data (Boynton et al., 2008), which might result in an underestimation of the inorganic $\mathrm{N}$ loading. In addition, all the input data were aggregated into the spatial resolution of $4 \mathrm{~km}$, which could also lead to a loss of information (e.g., the accurate distributions of precipitation, land-use, and manure and fertilizer applications within each grid cell) when simulating the riverine $\mathrm{N}$ export. Furthermore, model structure and parameterizations also can induce uncertainties in the DLEM simulations. Because we calibrated $\mathrm{N}$ loading based on different land-use types rather than for each sub-watershed, we can only ensure that DLEM simulated exports matched the LOADEST estimates in the large sub-watersheds (i.e., Susquehanna and Potomac River). For the smaller sub-watersheds (i.e., the James, Rappahannock, and York), the DLEM simulated N exports are roughly $20 \%$ higher than that of the LOADEST estimates (Table 1). In addition, the ungauged small watersheds in the coastal plain were not thoroughly validated due to the scarcity of observations in these regions. In the future, more work is needed to better represent $\mathrm{N}$ biogeochemical processes at the terrestrial-aquatic interface and to improve the geospatial data required to drive these types of mechanistic models (Boesch, 2020).

\section{Conclusions}

This study reconstructed N export to the Chesapeake Bay from 1900 to 2015 by applying DLEM with a state-of-the-art terrestrial-aquatic module that was capable of simulating the water and nutrient transport processes within each grid cell. The model results reported here agree well with those of the CBP's management model (CBP-Phase6) over the time period when they are available (1985-2014). Our simulated results estimated that annual fluxes of $\mathrm{NH}_{4}{ }^{+}, \mathrm{NO}_{3}{ }^{-}, \mathrm{DON}$, and PON from the CBW during 1900-2015 were 5.2, 79.8, 19.1, and 14.2 $\mathrm{Gg} \mathrm{N} \mathrm{y}^{-1}$, respectively; however, these fluxes underwent considerable change throughout this time period. $\mathrm{NH}_{4}{ }^{+}, \mathrm{NO}_{3}{ }^{-}$, and DON export from the CBW all increased before the 1990s and decreased thereafter, while PON showed little change. Precipitation is the primary reason for the interannual variability of riverine $\mathrm{N}$ export, with much higher amounts of TN export during extreme precipitation events. The yield rate changes of different $\mathrm{N}$ species indicated diverse spatial patterns throughout the watershed.

Different $\mathrm{N}$ species exhibited different responses to changes in multiple environmental factors. Wastewater, climate and land-use were the dominant factors causing change in riverine $\mathrm{NH}_{4}{ }^{+}$and DON, while land-use, atmospheric $\mathrm{N}$ deposition, and $\mathrm{N}$ fertilizer usage were the three primary factors for riverine $\mathrm{NO}_{3}{ }^{-}$changes. Precipitation and land conversion impacted riverine PON export in opposite ways: greater precipitation increased PON export, while conversion of agricultural lands decreased PON export. Overall, the key contributors to TN export in the rivers changed over the study period, from atmospheric N deposition (the 1930s to the 1960s) to precipitation (the 1970s), and ultimately to synthetic N fertilizer for 1980-2015. Land-use conversion from cropland to forest or grassland was the major factor that decreased TN export, and the effect of changes in land-use partially offset the effect of increasing anthropogenic $\mathrm{N}$ input on riverine $\mathrm{N}$ loading. Antipollution policies and implementation measures all played critical roles in the decrease of $\mathrm{N}$ export in recent decades, and further reduction in riverine $\mathrm{N}$ export will require more effective regulation on the application of $\mathrm{N}$ fertilizer.

\section{Conflict of Interest}

The authors declare no conflicts of interest relevant to this study.

\section{Data Availability Statement}

The model input and output data used in this study are archived in Box cloud storage of Auburn University (https://auburn.box.com/s/tbyz7a2ytcy40vmwfmfh182oja1jjxdg). 
Acknowledgments

This study has been supported in part by NASA Interdisciplinary Science Program (award number NNX14AF93G) and by the National Oceanic and Atmospheric Administration's National Centers for Coastal Ocean Science under award NA16NOS4780207 to the Virginia Institute of Marine Science. We appreciate Dr. Donald F. Boesch's detailed comments and suggestions on this study. The authors thank Drs. Gopal Bhatt, Scott Ator, and Gary Shenk for providing simulation data of the CBP-Phase 6 and SPARROW models.

\section{References}

Allen, G. H., Pavelsky, T. M., Barefoot, E. A., Lamb, M. P., Butman, D., Tashie, A., \& Gleason, C. J. (2018). Similarity of stream width distributions across headwater systems. Nature Communications, 9(1), 1-7. https://doi.org/10.1038/s41467-018-02991-w

Ator, S. W., Blomquist, J. D., Webber, J. S., \& Chanat, J. G. (2020). Factors driving nutrient trends in streams of the Chesapeake Bay watershed. Journal of Environmental Quality, 49(4), 812-834. https://doi.org/10.1002/jeq2.20101

Ator, S. W., García, A. M., Schwarz, G. E., Blomquist, J. D., \& Sekellick, A. J. (2019). Toward explaining nitrogen and phosphorus trends in Chesapeake Bay tributaries, 1992-2012. Journal of the American Water Resources Association, 55(5), 1149-1168. https://doi. org/10.1111/1752-1688.12756

Ballard, T., Sinha, E., \& Michalak, A. M. (2019). Long-term changes in precipitation and temperature have already impacted nitrogen loading. Environmental Science \& Technology, 53(9), 5080-5090. https://doi.org/10.1021/acs.est.8b06898

Bever, A. J., Friedrichs, M. A. M., Friedrichs, C. T., Scully, M. E., \& Lanerolle, L. W. J. (2013). Combining observations and numerical model results to improve estimates of hypoxic volume within the Chesapeake Bay, USA. Journal of Geophysical Research: Oceans, 118(10), 4924-4944. https://doi.org/10.1002/jgrc.20331

Boesch, D. F. (2020). It's time to match cleanup assumptions with results, not give up. Retrieved from https://www.bayjournal.com/opinion/ forum/it-s-time-to-match-cleanup-assumptions-with-results-not-give-up/article_8c5bbeda-0efb-11eb-9c8f-e3afbe8a7a01.html

Boesch, D. F., Brinsfield, R. B., \& Magnien, R. E. (2001). Chesapeake Bay eutrophication: Scientific understanding, ecosystem restoration, and challenges for agriculture. Journal of Environmental Quality, 30(2), 303-320. https://doi.org/10.2134/jeq2001.302303x

Boyer, E. W., Goodale, C. L., Jaworski, N. A., \& Howarth, R. W. (2002). Anthropogenic nitrogen sources and relationships to riverine nitrogen export in the northeastern U.S.A. Biogeochemistry, 57(1), 137-169. https://doi.org/10.1007/978-94-017-3405-9_4

Boyer, E. W., Howarth, R. W., Galloway, J. N., Dentener, F. J., Green, P. A., \& Vörösmarty, C. J. (2006). Riverine nitrogen export from the continents to the coasts. Global Biogeochemical Cycles, 20(1). https://doi.org/10.1029/2005gb002537

Boynton, W. R., Hagy, J. D., Cornwell, J. C., Kemp, W. M., Greene, S. M., Owens, M. S., et al. (2008). Nutrient budgets and management actions in the Patuxent River estuary, Maryland. Estuaries and Coasts, 31(4), 623-651. https://doi.org/10.1007/s12237-008-9052-9

Brush, G. S. (2009). Historical Land use, nitrogen, and coastal eutrophication: A paleoecological perspective. Estuaries and Coasts, 32(1), 18-28. https://doi.org/10.1007/s12237-008-9106-Z

Burgin, A. J., \& Hamilton, S. K. (2007). Have we overemphasized the role of denitrification in aquatic ecosystems? A review of nitrate removal pathways. Frontiers in Ecology and the Environment, 5(2), 89-96. https://doi.org/10.1890/1540-9295(2007)5[89:hwotro]2.0.c0;2

Chen, B., Chang, S. X., Lam, S. K., Erisman, J. W., \& Gu, B. (2017). Land use mediates riverine nitrogen export under the dominant influence of human activities. Environmental Research Letters, 12(9), 094018. https://doi.org/10.1088/1748-9326/aa84bc

Chesapeake Bay Program. (2017). Chesapeake Assessment and Scenario Tool (CAST) version 2017d. Chesapeake Bay Program Office

Da, F., Friedrichs, M. A. M., \& St-Laurent, P. (2018). Impacts of atmospheric nitrogen deposition and coastal nitrogen fluxes on oxygen concentrations in Chesapeake Bay. Journal of Geophysical Research: Oceans, 123(7), 5004-5025. https://doi.org/10.1029/2018JC014009

Davidson, E. A., David, M. B., Galloway, J. N., Goodale, C. L., Haeuber, R., Harrison, J. A., et al. (2011). Excess nitrogen in the US environment: Trends, risks, and solutions. Issues in Ecology, 15.

Dentener, F. J. (2006). Global maps of atmospheric nitrogen deposition, 1860, 1993, and 2050. ORNL DAAC. https://doi.org/10.3334/ ORNLDAAC $/ 830$

Donner, S. D., Kucharik, C. J., \& Oppenheimer, M. (2004). The influence of climate on in-stream removal of nitrogen. Geophysical Research Letters, 31(20). https://doi.org/10.1029/2004gl020477

Du, E., de Vries, W., Galloway, J. N., Hu, X., \& Fang, J. (2014). Changes in wet nitrogen deposition in the United States between 1985 and 2012. Environmental Research Letters, 9(9), 095004. https://doi.org/10.1088/1748-9326/9/9/095004

Dupas, R., Minaudo, C., Gruau, G., Ruiz, L., \& Gascuel-Odoux, C. (2018). Multidecadal trajectory of riverine nitrogen and phosphorus dynamics in rural catchments. Water Resources Research, 54(8), 5327-5340. https://doi.org/10.1029/2018wr022905

Eshleman, K. N., \& Sabo, R. D. (2016). Declining nitrate-N yields in the Upper Potomac River Basin: What is really driving progress under the Chesapeake Bay restoration? Atmospheric Environment, 146, 280-289. https://doi.org/10.1016/j.atmosenv.2016.07.004

Feng, Y., Friedrichs, M. A. M., Wilkin, J., Tian, H., Yang, Q., Hofmann, E. E., et al. (2015). Chesapeake Bay nitrogen fluxes derived from a land-estuarine ocean biogeochemical modeling system: Model description, evaluation, and nitrogen budgets. Journal of Geophysical Research: Biogeosciences, 120(8), 1666-1695. https://doi.org/10.1002/2015jg002931

Friedrichs, M. A. M., St-Laurent, P., Xiao, Y., Hofmann, E., Hyde, K., Mannino, A., et al. (2019). Ocean circulation causes strong variability in the mid-Atlantic bight nitrogen budget. Journal of Geophysical Research: Oceans, 124(1), 113-134. https://doi.org/10.1029/2018JC014424

Galloway, J. N., Dentener, F. J., Capone, D. G., Boyer, E. W., Howarth, R. W., Seitzinger, S. P., et al. (2004). Nitrogen cycles: Past, present, and future. Biogeochemistry, 70(2), 153-226. https://doi.org/10.1007/s10533-004-0370-0

Gardner, J. R., Fisher, T. R., Jordan, T. E., \& Knee, K. L. (2016). Balancing watershed nitrogen budgets: Accounting for biogenic gases in streams. Biogeochemistry, 127(2-3), 231-253. https://doi.org/10.1007/s10533-015-0177-1

Gergel, S. E., Carpenter, S. R., \& Stanley, E. H. (2005). Do dams and levees impact nitrogen cycling? Simulating the effects of flood alterations on floodplain denitrification. Global Change Biology, 11(8), 1352-1367. https://doi.org/10.1111/j.1365-2486.2005.00966.x

Gheysari, M., Mirlatifi, S. M., Homaee, M., Asadi, M. E., \& Hoogenboom, G. (2009). Nitrate leaching in a silage maize field under different irrigation and nitrogen fertilizer rates. Agricultural Water Management, 96(6), 946-954. https://doi.org/10.1016/j.agwat.2009.01.005

Gleick, P. H. (1989). Climate change, hydrology, and water resources. Reviews of Geophysics, 27(3), 329-344. https://doi.org/10.1029/ RG027i003p00329

Goodale, C. L., Aber, J. D., \& McDowell, W. H. (2000). The long-term effects of disturbance on organic and inorganic nitrogen export in the White Mountains, New Hampshire. Ecosystems, 3(5), 433-450. https://doi.org/10.1007/s100210000039

Hagy, J. D., Boynton, W. R., Keefe, C. W., \& Wood, K. V. (2004). Hypoxia in Chesapeake Bay, 1950-2001: Long-term change in relation to nutrient loading and river flow. Estuaries, 27(4), 634-658. https://doi.org/10.1007/BF02907650

Harding, L. W., Gallegos, C. L., Perry, E. S., Miller, W. D., Adolf, J. E., Mallonee, M. E., \& Paerl, H. W. (2016a). Long-term trends of nutrients and phytoplankton in Chesapeake Bay. Estuaries and Coasts, 39(3), 664-681. https://doi.org/10.1007/s12237-015-0023-7

Harding, L. W., Mallonee, M. E., Perry, E. S., Miller, W. D., Adolf, J. E., Gallegos, C. L., \& Paerl, H. W. (2016b). Variable climatic conditions dominate recent phytoplankton dynamics in Chesapeake Bay. Scientific Reports, 6(1). https://doi.org/10.1038/srep23773

Harding, L. W., Mallonee, M. E., Perry, E. S., Miller, W. D., Adolf, J. E., Gallegos, C. L., \& Paerl, H. W. (2019). Long-term trends, current status, and transitions of water quality in Chesapeake Bay. Scientific Reports, 9(1), 6709. https://doi.org/10.1038/s41598-019-43036-6

Havlin, J. L., Tisdale, S. L., Nelson, W. L., \& Beaton, J. D. (2016). Soil fertility and fertilizers. Pearson Education India. 
Howarth, R., Swaney, D., Billen, G., Garnier, J., Hong, B., Humborg, C., et al. (2012). Nitrogen fluxes from the landscape are controlled by net anthropogenic nitrogen inputs and by climate. Frontiers in Ecology and the Environment, 10(1), 37-43. https://doi.org/10.1890/100178

Howarth, R. W., Swaney, D. P., Boyer, E. W., Marino, R., Jaworski, N., \& Goodale, C. (2006). The influence of climate on average nitrogen export from large watersheds in the Northeastern United States. In Nitrogen cycling in the Americas: Natural and anthropogenic influences and controls (pp. 163-186). Springer.

Iqbal, J., Necpalova, M., Archontoulis, S. V., Anex, R. P., Bourguignon, M., Herzmann, D., et al. (2018). Extreme weather-year sequences have nonadditive effects on environmental nitrogen losses. Global Change Biology, 24(1), e303-e317. https://doi.org/10.1111/gcb.13866

Irby, I. D., \& Friedrichs, M. A. M. (2019). Evaluating confidence in the impact of regulatory nutrient reduction on Chesapeake Bay water quality. Estuaries and Coasts, 42(1), 16-32. https://doi.org/10.1007/s12237-018-0440-5

Jolliff, J. K., Kindle, J. C., Shulman, I., Penta, B., Friedrichs, M. A. M., Helber, R., \& Arnone, R. A. (2009). Summary diagrams for coupled hydrodynamic-ecosystem model skill assessment. Journal of Marine Systems, 76(1-2), 64-82. https://doi.org/10.1016/j.jmarsys.2008.05.014

Kemp, W., Boynton, W., Adolf, J., Boesch, D., Boicourt, W., Brush, G., et al. (2005). Eutrophication of Chesapeake Bay: Historical trends and ecological interactions. Marine Ecology Progress Series, 303, 1-29. https://doi.org/10.3354/meps303001

Klein Goldewijk, K., Beusen, A., Doelman, J., \& Stehfest, E. (2017). Anthropogenic land use estimates for the Holocene-HYDE 3.2. Earth System Science Data, 9(2), 927-953. https://doi.org/10.5194/essd-9-927-2017

Lefcheck, J. S., Orth, R. J., Dennison, W. C., Wilcox, D. J., Murphy, R. R., Keisman, J., et al. (2018). Long-term nutrient reductions lead to the unprecedented recovery of a temperate coastal region. Proceedings of the National Academy of Sciences of the United States of America, 115(14), 3658-3662. https://doi.org/10.1073/pnas.1715798115

Li, H., Wigmosta, M. S., Wu, H., Huang, M., Ke, Y., Coleman, A. M., \& Leung, L. R. (2013). A physically based runoff routing model for land surface and earth system models. Journal of Hydrometeorology, 14(3), 808-828. https://doi.org/10.1175/jhm-d-12-015.1

Li, H.-Y., Leung, L. R., Getirana, A., Huang, M., Wu, H., Xu, Y., et al. (2015). Evaluating global streamflow simulations by a physically based routing model coupled with the community land model. Journal of Hydrometeorology, 16(2), 948-971. https://doi.org/10.1175/ jhm-d-14-0079.1

Liu, C., Zou, C., Wang, Q., Hayashi, Y., \& Yasunari, T. (2014). Impact assessment of human diet changes with rapid urbanization on regional nitrogen and phosphorus flows-A case study of the megacity Shanghai. Environmental Science \& Pollution Research, 21(3), 1905-1914. https://doi.org/10.1007/s11356-013-2006-1

Liu, M., Tian, H., Yang, Q., Yang, J., Song, X., Lohrenz, S. E., \& Cai, W.-J. (2013). Long-term trends in evapotranspiration and runoff over the drainage basins of the Gulf of Mexico during 1901-2008. Water Resources Research, 49(4), 1988-2012. https://doi.org/10.1002/ wrcr.20180

Lu, C., \& Tian, H. (2017). Global nitrogen and phosphorus fertilizer use for agriculture production in the past half century: Shifted hot spots and nutrient imbalance. Earth System Science Data, 9, 181. https://doi.org/10.5194/essd-9-181-2017

McCuen, R. H., Knight, Z., \& Cutter, A. G. (2006). Evaluation of the Nash-Sutcliffe efficiency index. Journal of Hydrologic Engineering, 11(6), 597-602. https://doi.org/10.1061/(asce)1084-0699(2006)11:6(597)

Pan, S., Tian, H., Dangal, S. R. S., Ouyang, Z., Lu, C., Yang, J., et al. (2015). Impacts of climate variability and extremes on global net primary production in the first decade of the 21st century. Journal of Geographical Sciences, 25(9), 1027-1044. https://doi.org/10.1007/ s11442-015-1217-4

Pan, S., Yang, J., Tian, H., Shi, H., Chang, J., Ciais, P., et al. (2020). Climate Extreme Versus Carbon Extreme: Responses of Terrestrial Carbon Fluxes to Temperature and Precipitation. Journal of Geophysical Research: Biogeosciences, 125(4), e2019JG00525. https://doi. org/10.1029/2019JG005252

Poor, C. J., \& McDonnell, J. J. (2007). The effects of land use on stream nitrate dynamics. Journal of Hydrology, 332(1-2), 54-68. https:// doi.org/10.1016/j.jhydrol.2006.06.022

Portmann, F. T., Siebert, S., \& Döll, P. (2010). MIRCA2000-Global monthly irrigated and rainfed crop areas around the year 2000: A new high-resolution data set for agricultural and hydrological modeling. Global Biogeochemical Cycles, 24(1). https://doi. org/10.1029/2008gb003435

Prasad, M. B. K., Sapiano, M. R. P., Anderson, C. R., Long, W., \& Murtugudde, R. (2010). Long-term variability of nutrients and chlorophyll in the Chesapeake Bay: A retrospective analysis, 1985-2008. Estuaries and Coasts, 33(5), 1128-1143. https://doi.org/10.1007/ s12237-010-9325-y

Reis, S., Pinder, R. W., Zhang, M., Lijie, G., \& Sutton, M. A. (2009). Reactive nitrogen in atmospheric emission inventories. Atmospheric Chemistry and Physics, 9(19), 7657-7677. https://doi.org/10.5194/acp-9-7657-2009

Ren, W., Tian, H., Cai, W.-J., Lohrenz, S. E., Hopkinson, C. S., Huang, W.-J., et al. (2016). Century-long increasing trend and variability of dissolved organic carbon export from the Mississippi River basin driven by natural and anthropogenic forcing. Global Biogeochemical Cycles, 30(9), 1288-1299. https://doi.org/10.1002/2016gb005395

Roberts, A. D., \& Prince, S. D. (2010). Effects of urban and non-urban land cover on nitrogen and phosphorus runoff to Chesapeake Bay. Ecological Indicators, 10(2), 459-474. https://doi.org/10.1016/j.ecolind.2009.07.017

Royer, T. V., David, M. B., \& Gentry, L. E. (2006). Timing of riverine export of nitrate and phosphorus from agricultural watersheds in Illinois: Implications for reducing nutrient loading to the Mississippi River. Environmental Science \& Technology, 40(13), 4126-4131. https://doi.org/10.1021/es052573n

Runkel, R. L., Crawford, C. G., \& Cohn, T. A. (2004). Load estimator (LOADEST): A FORTRAN program for estimating constituent loads in streams and rivers.

Scavia, D., Kelly, E. L. A., \& Hagy, J. D. (2006). A simple model for forecasting the effects of nitrogen loads on Chesapeake Bay hypoxia. Estuaries and Coasts, 29(4), 674-684. https://doi.org/10.1007/bf02784292

Schlesinger, W. H., \& Bernhardt, E. S. (2013). Biogeochemistry: An analysis of global change. Academic Press.

Schlesinger, W. H., Reckhow, K. H., \& Bernhardt, E. S. (2006). Global change: The nitrogen cycle and rivers. Water Resources Research, 42(3). https://doi.org/10.1029/2005wr004300

Seitzinger, S. P., Styles, R. V., Boyer, E. W., Alexander, R. B., Billen, G., Howarth, R. W., et al. (2002). Nitrogen retention in rivers: Model development and application to watersheds in the northeastern U.S.A. In E. W. Boyer \& R. W. Howarth (Eds.), The nitrogen cycle at regional to global scales (pp. 199-237). Springer. https://doi.org/10.1007/978-94-017-3405-9_6

Shenk, G. W., \& Linker, L. C. (2013). Development and application of the 2010 Chesapeake Bay watershed total maximum daily load model. Journal of the American Water Resources Association, 49(5), 1042-1056. https://doi.org/10.1111/jawr.12109

Shields, C. A., Band, L. E., Law, N., Groffman, P. M., Kaushal, S. S., Savvas, K., et al. (2008). Streamflow distribution of nonpoint source nitrogen export from urban-rural catchments in the Chesapeake Bay watershed. Water Resources Research, 44(9). https://doi.org/10.1029/2007wr006360 
Sinha, E., \& Michalak, A. M. (2016). Precipitation dominates interannual variability of riverine nitrogen loading across the continental United States. Environmental Science \& Technology, 50(23), 12874-12884. https://doi.org/10.1021/acs.est.6b04455

Sinha, E., Michalak, A. M., \& Balaji, V. (2017). Eutrophication will increase during the 21st century as a result of precipitation changes. Science, 357(6349), 405-408. https://doi.org/10.1126/science.aan2409

Strickling, H. L., \& Obenour, D. R. (2018). Leveraging spatial and temporal variability to probabilistically characterize nutrient sources and export rates in a developing watershed. Water Resources Research, 54(7), 5143-5162. https://doi.org/10.1029/2017wr022220

Tango, P. J., \& Batiuk, R. A. (2016). Chesapeake Bay recovery and factors affecting trends: Long-term monitoring, indicators, and insights. Regional Studies in Marine Science, 4, 12-20. https://doi.org/10.1016/j.rsma.2015.11.010

Tango, P. J., Magnien, R., Butler, W., Luckett, C., Luckenbach, M., Lacouture, R., \& Poukish, C. (2005). Impacts and potential effects due to Prorocentrum minimum blooms in Chesapeake Bay. Harmful Algae, 4(3), 525-531. https://doi.org/10.1016/j.hal.2004.08.014

Te Chow, V. (2010). Applied hydrology. Tata McGraw-Hill Education.

Terziotti, S., Capel, P. D., Tesoriero, A. J., Hopple, J. A., \& Kronholm, S. C. (2018). Estimates of nitrate loads and yields from groundwater to streams in the Chesapeake Bay watershed based on land use and geology. US Geological Survey. https://doi.org/10.3133/sir20175160

Testa, J. M., Kemp, W. M., \& Boynton, W. R. (2018). Season-specific trends and linkages of nitrogen and oxygen cycles in Chesapeake Bay. Limnology \& Oceanography, 63(5), 2045-2064. https://doi.org/10.1002/lno.10823

Testa, J. M., Li, Y., Lee, Y. J., Li, M., Brady, D. C., Di Toro, D. M., et al. (2014). Quantifying the effects of nutrient loading on dissolved $\mathrm{O}_{2}$ cycling and hypoxia in Chesapeake Bay using a coupled hydrodynamic-biogeochemical model. Journal of Marine Systems, 139, 139-158. https://doi.org/10.1016/j.jmarsys.2014.05.018

Thomann, R. V., \& Mueller, J. A. (1987). Principles of surface water quality modeling and control. Harper \& Row Publishers.

Tian, H., Chen, G., Liu, M., Zhang, C., Sun, G., Lu, C., et al. (2010). Model estimates of net primary productivity, evapotranspiration, and water use efficiency in the terrestrial ecosystems of the southern United States during 1895-2007. Forest Ecology and Management, 259(7), 1311-1327. https://doi.org/10.1016/j.foreco.2009.10.009

Tian, H., Lu, C., Ciais, P., Michalak, A. M., Canadell, J. G., Saikawa, E., et al. (2016). The terrestrial biosphere as a net source of greenhouse gases to the atmosphere. Nature, 531(7593), 225. https://doi.org/10.1038/nature16946

Tian, H., Lu, C., Melillo, J., Ren, W., Huang, Y., Xu, X., et al. (2012). Food benefit and climate warming potential of nitrogen fertilizer uses in China. Environmental Research Letters, 7(4), 044020. https://doi.org/10.1088/1748-9326/7/4/044020

Tian, H., Xu, R., Pan, S., Yao, Y., Bian, Z., Cai, W.-J., et al. (2020). Long-term trajectory of nitrogen loading and delivery from Mississippi River Basin to the Gulf of Mexico. Global Biogeochemical Cycles, 34(5), e2019GB006475. https://doi.org/10.1029/2019GB006475

Tian, H., Yang, J., Xu, R., Lu, C., Canadell, J., Davidson, E., et al. (2019). Global soil nitrous oxide emissions since the preindustrial era estimated by an ensemble of terrestrial biosphere models: Magnitude, attribution, and uncertainty. Global Change Biology, 25(2), 640-659. https://doi.org/10.1111/gcb.14514

Tian, H., Yang, Q., Najjar, R. G., Ren, W., Friedrichs, M. A. M., Hopkinson, C. S., \& Pan, S. (2015). Anthropogenic and climatic influences on carbon fluxes from eastern North America to the Atlantic Ocean: A process-based modeling study. Journal of Geophysical Research: Biogeosciences, 120(4), 757-772. https://doi.org/10.1002/2014jg002760

Van Drecht, G., Bouwman, A. F., Harrison, J., \& Knoop, J. M. (2009). Global nitrogen and phosphate in urban wastewater for the period 1970 to 2050. Global Biogeochemical Cycles, 23(4). https://doi.org/10.1029/2009gb003458

Wagena, M. B., Collick, A. S., Ross, A. C., Najjar, R. G., Rau, B., Sommerlot, A. R., et al. (2018). Impact of climate change and climate anomalies on hydrologic and biogeochemical processes in an agricultural catchment of the Chesapeake Bay watershed, USA. The Science of the Total Environment, 637-638, 1443-1454. https://doi.org/10.1016/j.scitotenv.2018.05.116

Waisanen, P. J., \& Bliss, N. B. (2002). Changes in population and agricultural land in conterminous United States counties, 1790 to 1997. Global Biogeochemical Cycles, 16(4), 84-1-84-19. https://doi.org/10.1029/2001gb001843

Wang, P., Linker, L. C., \& Shenk, G. W. (2016). Using geographically isolated loading scenarios to analyze nitrogen and phosphorus exchanges and explore tailored nutrient control strategies for efficient management. Environmental Modeling \& Assessment, 21(3), 437454. https://doi.org/10.1007/s10666-015-9487-x

Xu, R., Tian, H., Pan, S., Prior, S. A., Feng, Y., Batchelor, W. D., et al. (2019). Global ammonia emissions from synthetic nitrogen fertilizer applications in agricultural systems: Empirical and process-based estimates and uncertainty. Global Change Biology, 25(1), 314-326. https://doi.org/10.1111/gcb.14499

Xu, R. T., Pan, S. F., Chen, J., Chen, G. S., Yang, J., Dangal, S. R. S., et al. (2018). Half-century ammonia emissions from agricultural systems in Southern Asia: Magnitude, spatiotemporal patterns, and implications for human health. GeoHealth, 2(1), 40-53. https://doi. org/10.1002/2017gh000098

Yang, Q., Tian, H., Friedrichs, M. A. M., Hopkinson, C. S., Lu, C., \& Najjar, R. G. (2015). Increased nitrogen export from eastern North America to the Atlantic Ocean due to climatic and anthropogenic changes during 1901-2008. Journal of Geophysical Research: Biogeosciences, 120(6), 1046-1068. https://doi.org/10.1002/2014jg002763

Yang, Q., Tian, H., Li, X., Ren, W., Zhang, B., Zhang, X., \& Wolf, J. (2016). Spatiotemporal patterns of livestock manure nutrient production in the conterminous United States from 1930 to 2012. The Science of the Total Environment, 541, 1592-1602. https://doi.org/10.1016/j scitotenv.2015.10.044

Yao, Y., Tian, H., Shi, H., Pan, S., Xu, R., Pan, N., \& Canadell, J. G. (2020). Increased global nitrous oxide emissions from streams and rivers in the Anthropocene. Nature Climate Change, 10(2), 138-142. https://doi.org/10.1038/s41558-019-0665-8

Zhang, Q., Brady, D. C., Boynton, W. R., \& Ball, W. P. (2015). Long-term trends of nutrients and sediment from the Nontidal Chesapeake Watershed: An assessment of progress by river and season. Journal of the American Water Resources Association, 51(6), 1534-1555. https://doi.org/10.1111/1752-1688.12327

Zhang, Q., Murphy, R. R., Tian, R., Forsyth, M. K., Trentacoste, E. M., Keisman, J., \& Tango, P. J. (2018). Chesapeake Bay's water quality condition has been recovering: Insights from a multimetric indicator assessment of thirty years of tidal monitoring data. The Science of the Total Environment, 637-638, 1617-1625. https://doi.org/10.1016/j.scitotenv.2018.05.025

Zhang, W., Swaney, D. P., Hong, B., Howarth, R. W., \& Li, X. (2017). Influence of rapid rural-urban population migration on riverine nitrogen pollution: Perspective from ammonia-nitrogen. Environmental Science \& Pollution Research, 24(35), 27201-27214. https://doi. org/10.1007/s11356-017-0322-6

Zhu, Y., Chen, L., Wei, G., Li, S., \& Shen, Z. (2019). Uncertainty assessment in baseflow nonpoint source pollution prediction: The impacts of hydrographic separation methods, data sources and baseflow period assumptions. Journal of Hydrology, 574, 915-925. https://doi. org/10.1016/j.jhydrol.2019.05.010 